University of Rhode Island

DigitalCommons@URI

Open Access Master's Theses

1979

\title{
A Psychophysiological Investigation of Sexual Responding in Heterosexual Males and Females
}

Debra L. Steinman

University of Rhode Island

Follow this and additional works at: https://digitalcommons.uri.edu/theses

\section{Recommended Citation}

Steinman, Debra L., "A Psychophysiological Investigation of Sexual Responding in Heterosexual Males and Females" (1979). Open Access Master's Theses. Paper 1719.

https://digitalcommons.uri.edu/theses/1719

This Thesis is brought to you for free and open access by DigitalCommons@URI. It has been accepted for inclusion in Open Access Master's Theses by an authorized administrator of DigitalCommons@URI. For more information, please contact digitalcommons-group@uri.edu. 
A Psychophysioiogical Investigation of

Sexual Responding ir.

Heterosexua 1 Males and Females

by

Debra L. Steinman

A thesis submitted in partial fulfillment of the

requirements for the degree of

Mastor of Arts

in

Clinical Psychology

University of khode Is? and

1979 
Abstract

\author{
A Psychophysiological Investigation of \\ Sexual Responding in \\ Heterosexual Males and Females
}

This study evaluates and compares the subjective and physiological arousal responses of heterosexual males and heterosexual females. Although several researchers have studied the patterns of sexual responding in reaction to erotic stimulation for ma?es and/or females (hincze, Hoon \& Hoon, 1977; Heiman, 1977; and Sanford, 1974), to date there has been no systematic attempt to compare the patterns of sexual responding for these two groups using comparable measuring devices. With the recent development of more sensitive measuring devices, it is now possible to research this area.

The goals of this study were several; (1) to evaluate and compare males' and females' differential patterns of physiological responsivity to a variety of erotic stimuli, (2) to evaluate and compare differential patterns of subjective responsivity for males and females, (3) to examine the relationship between measures of the physiological arousal response and the reported subjective arousal for males and females, and (4) to determine the extent to which a surface photoplythesmograph transducer was capable of discriminating sexual arousal from nonarousal states for males.

Methodologically, a group comparison paradign was employed. Eight males and eight females were shown a variety of erotic and nonerotic films. The films were sequentially presented thell withdrawn. During 
this time, both physiological ans subjective measures of sexual arousal were continuously recorded. Dependent measures included vaginal vasocongestion, perile circumference, penile vasccongestion, and continuous report of subjective arousal. In addition, several self-report instruments designed to ascertain sexual experience and behavior, sexual arousability, sexual attitudes, and sex-role stereotypes were administered.

The results of this investigation indicate that for both males and females the erotic film sequences produced significantly more sexual arousal than the neutral film. Males and females differed in their physiological responses to erotic film content. The males displayed the highest levels of physiological arousal in the presence of the group sex and lesbian activity films. The highest levels of physiological arousal for the females were observed in the presence of the group sex and heterosexual activity films. A film depicting male homosexual behavior produced the least sexual arousal for the males as well as for the females. These results are discussed in terms of a model of social acceptability/unacceptability. Differences between the two groups' subjective reports of sexual arousal were also observed. The males reported the highest levels of subjective arousal during a group sex film. The females reported being the most subjectively aroused in the presence of a heterosexual activity film. There were significant correlations between penile circumference and subjective arousal for all of the males. However, the relationship between vaginal vasocongestion and subjective arousal was significantly high for only 5 of the 8 females. The measure 
of penile vasocongestion did not discruminte between aroused and nonaroused states for the maies. Potential reasons for this finding were discussed. Suggestions were made for the development of more refined instrumentation for assessing sexual arousal. 
Acknowledgements.

To the SEX TEAM and to my conmittee members, whose enthusiasm and assistance made this possible...

To David, whose alıiance, commitment, nard work, and humor made this happen...

And to Warren, whose love makes this, as everything, worthwhile. 
Table of Contens

Abstract

Page

Acknowiedgements.

$-i-$

List of Tables

- vii-

List of Figures

-viii-

Introduction

Arousal Patterns: Heterosexual and Homosexual Mries

Arousal Patterns: Normal and Dysfunctional

Females

Arousal Patterns: Male vs. Female . . . . . . 5

Arcusal Patterns: Heterosexual, Homosexual

and Transsexual Males . . . . . . . . . . . 7

Summary . • . . . . . . . . . . . . . 8

Subjects . . . . . . . . . . . . . . . 12

Measures .................... 13

Behavioral Measures .. . . . . . . . . 13

Subjective Measures . . . . . . . . . . . 14

Physiological Measures . . . . . . . . . . 16

Experimental Design . . . . . . . . . . . 18

Experimental Session . . . . . . . . . . . . . 19

Data Sampling . . . . . . . . . . . . . 21

Data Analysis . . . . . . . . . . . . . . 21

Results.................... . 22

Analysis for Males . . . . . . . . . . . 23

Analysis for Females . . . . . . . . . . . 27 
Comparison of Objective anc

Subjective Measures . . . . . . . . . . . 29

Demographic Measures .. . . . . . . . . 30

Discussion . . . . . . . . . . . . . . . 31

Male and Female Differential

Patterns of Physiological

Responding to Erotica . . . . . . . . . . 31

Differential Patterns of

Subjective Responding to

Erotica . . . . . . . . . . . 38

Reiationship Between Objective

and Subjective Measures . . . . . . . . . 39

Subjects..................... 41

The Surface Photoplythesmograph

as a Measure of Arousal . . . . . . . . . . 42

Future Directions .... . . . . . . . . . . 44

References .................. . . . 4 46

Tables .................... . . . 49

Figures .. . . . . . . . . . . . . . 66

Appendices ................... . . . 71 
List of Tables

Table I Cell Means and Standard Deviations for the Male Penile Circumference Data

Table 2 ANOVA Sumary Table for Male Perile Circumference Data

Table 3 Summary of Newman-Keuls Analysis of Male Penile Circumference Data

Table 4 Celi Means and Standard Deviations for the Male Penile Vasocongestion Data

Table 5 ANOVA Sumnary Table for Male Penile Vasocongestior Data

Table 6 Cell Means and Standard Deviations for the Male Penile Vasocongestion Data: Comparison of the Acquisition, Maintenance and Detumescence Phases of the Erectile Response

Table 7 ANOV'A Summary Table for the $3 x 6$ Male Penile Vasocongestion Data

Table $\delta$ Cell Means and Standard Deviations for the Male Continuous Subjective Arousal Data

Table 9 ANOVA Summary Table for Male Continuous Subjective Arousal Data

Table 10 Newman-Keuls Analysis of Male Subjective Arousal Data

Table 11 Cell Means and Standard Deviations for Female Vaginal Vasocongestion Data

Table 12 ANOVA Sumary Table for Female Vaginal Vasocongestion Data

Table 13 Newman-Keuis Analysis of Female Vaginal Vasocongestion Data

Table 14 Cell Means and Standard Deviations for Female Continuous Subjective Arousal Data

Table 15 ANOVA Sumary Table for Female Subjective Arousal Data

Table 16 Newman-Keuls Analysis of Female Subjective Arousal Data

Table 17 Individual Subjects Correlations Between Subjective and objective !easures of Sexual Arousal 
List of Figures

Figure 1 Male Perile Circumference Data

Figure 2 Male Subjective Arousal Data

Figure 3 Female Subjective Arousal Data

Figure 4 Comparison of Male and Female Mean Subjective Arousal Data

Figure 5 Polygraph Record of Male Arousal Response 
Introduction

Within the last decade, seintists have begun to systematically study sexual behavior and sexual arousal patterns. As a result of the early work of Masters and Johnson (1966), the avenues of exploration in the area of sexual behavior and arousal were opened. Although Masters and Johnscn's studies provided only descriptive data of sexual behavior, their pioneering work served to lift the social taboos against the laboratory study of sexual responding.

As Zuckerman (1971) points out in an early review, the most valid measure of sexual responding is a direct genital measure. With the development of objective measures of genital arousal for both males (Freund, 1957; Barlow, Becker, Leitenberg \& Agras, 1970) and females (Geer, Morokoff \& Greenwood, 1974), reports of investigations of sexual arousal patterns in a variety of populations have begun to appear in the literature. Researchers have studied the sexual arousal patterns of populations including heterosexual males and females, homosexual nales, sexually dysfunctional females, and pre-surgical male transsexuals. In addition, questions have been asked regarding the parameters of the sexual response. For example, which stimulus content elicit the greatest arousal responses, which stimulus modality is the most efficacious for evoking an arousal response, what is the relationship between objective and subjective measures of arousal?

Although a fair amount of work has been done studying the arousal patterns of normal, deviant, and dysfunctional individuals, to date it has been impossible to make direct comparisons of the male and the 
female sexual response. Typically, changes in vaginal vasocongestion have been used to indicate the presence of female sexual arousal and penile circumference change has been used as an indice of male sexual arousal.

In the review which follows, studies will be presented by population. Since questions regarding the parameters of the sexual response have, in most cases, been addressed within the context of a study evaluating patterns of sexual responding for a given population, the discussion of these issues will be included individually for each population. A summary of the research findings will follow the review.

\section{Arousal Patterns:}

Heterosexual and Homosexual Males

Several studies have assessed the arousal patterns of heterosexual males. Sanford (1974) reports that for 6 males, viewing films depicting a heterosexual couple actively engaging in intercourse produced a significantly greater increase in objective measures of sexual arousal than viewing films of nudity. It was also found that films elicited greater changes in measures of arousal than did slides depicting the same content. This finding was replicated by McConaghy (1974). In a comparison of 6 male heterosexuals to 6 male homosexuals, Mavissakalian, Blanchard, Abel and Barlow (1975) found that heterosexual activity and single nudefemale films did not differentiate between the two groups on measures of subjective and objective sexual arousal, as well as subjective ratings of "pleasantness." Both a lesbian and a homosexual film significantly differentiated between the two groups on all three 
dependent measures; the heterosexual group showing greater arousal responses to the lesbian film and the howosema? group showing greater arousal responses to the homosexual film. For 10 of the $12 \mathrm{Ss}$, a significant correlation was found between the objective arousal response and subjective report of sexual arousal.

In an attempt to evaluate the stimulus modality of choice as well as the effect of voluntary suppression, Abel, Barlow, Blanchard and Mavissakalian (1975) measured the erectile responses of 20 male hemosexual Ss under two instruction conditions (arousal and suppression), and three stimulus modality conditions (videotape, slides \& audiotape). Their results indicate that videotaped stimuli produce the greatest erectile response and that Ss could voluntarily suppress erection under both the videotape and slide conditions. However, even under the suppression condition, the videotaped stimuli elicited approximately $50 \%$ of full erection. In a clinical outcome study of 4 male homosexuals, Conrad and Wincze (1976) evaluated the effects of orgasmic reconditioning upor each S's objective levels of arousal responses to heterosexual and homosexual stimuli as well as each S's behavioral sexual arousal patterns. Results of this study indicate that although the Ss reported having improved as a result of the orgasmic reconditioning therapy, there was no change in objective and behavioral measures of sexual arousal. In summary, the studies reported above suggest that videotaped erotic stimuli produce the highest levels of arousal on both objective and subjective measures. Furthermore, even in the presence of voluntary suppression, videotaped stimuli elicit moderate level arousal responses. 
bifferential diagnosis of heterosexual versus homosexual male may be estabilshed by analyzing objectrve and shijective arousal responses to ] Esbian and homosexual activity films. And finaliy, direct objective measures of the erectile response may provide a useful means for evaluating treatment outcome.

\section{Arousal Pattems:}

Normal and Dysfunctional Females

In a physiological assessment of sexual arousal ir females, Hoon, Wincze and Hoon (1976), found vaginal blood pulse amplitude to be the most reliable measure of arousal when compared to a variety of other physiological measures. Wincze, Hoon and Hoon (1975) compared the sexual responsivity of dysfunctional and normal females. Their results indicate that measures of vaginal blood pulse amplitude and systolic blood pressure discriminate between the two groups, the normals showing higher levels of arousal to erotic stimuli. An interesting finding was that normals reported less subjective arousal than the physiological recordings indicated, whereas the dysfunctionals reported greater leveis of subjective arousal than their objective measures would indicate. The authors suggest that this finding may be due to the demand of the experimental setting upon the dysfunctional group. The only self-report measure which differentiated between the two groups was a rating of satisfaction with sexual responsivity. As a result of a stlidy comparing the cogritive and physiological arousal responses of normal females, wincze, Hoon and Hoon (1977) suggest that the "relationship between the cognitive and physiological indices of sexual arousal is greater in 
sexually experienced women" (p. 132). Their data also suggest that vaginal blood pulse amplitude was greatest in response to explicit group sex scenes, but that following the experimental session, none of the Ss reported these scenes to be the most erotic. Overall, the Ss preferred intercourse and oral sex scenes. There were no changes in physiological or subjective arousal in response to male homosexual scenes. In summary, the studies of female sexual responsivity reported herein indicate that measures of vaginal blood pulse amplitude are the most reliable indicators of sexual arousal, and that in the presence of erotic stimuli, these measures can differentiate between groups of normal and dysfunctional females. The discrepancies between self-report and physiological ineasures of sexual arousal suggest that demand and social taboos may significantly affect a female's self-report. These findings are especjally important since in most clinical settings assessment of a female's sexual behavior and arousal is done via interview. An interesting difference between male and female arousal patterns appears to exist. It seems that erotic lesbian stimuli produce both physiological and subjective increases in sexual arousal responses for males, but that erotic male homosexual stimuli produce no changes in sexual arousal on either measure for females.

\section{Arousal Patterns:}

Male vs. Female

In an assessment of male and female differences in subjective ratings of erotic stimuli, Steele and Walker (1974) found significant differences between the two groups. Males tended to rate slides which 
were considered to be more extreme (e.g., sadomasochism, homosexual cunnilingus, heterosexual feilatio) higher than females, who seemed to prefer more moderate slides (e.g., nude nales with exposed genitalia). Although both males and females reported minimal sexual stimulation and minimal jiking for the slides, the male's ratings were higher on both scales. The authors suggest that "males are more responsive to visual erotic stimuli than are females" (p. 463). Heiman (1978) compared the subjective and objective arousal patterns in males and females and found that for both groups the amount of previous sexual experience had no effect upon measures of sexual arousal to erotic films. For females, it was found that a nontraditional, female-initiated, female-centered film was most physiologically arousing. This author suggests that "perhaps erotica must be socially unacceptable or norm breaking, in order to be maximally arousing" (p. 15). Although there were significant correlations between objective measures of arousal (genital pulse amplitude) and subjective measures for both groups, the relationship was less reliable for females. It is interesting that in the presence of high levels of arousal, $42 \%$ of the females reported no subjective experience of arousal. This was not the case for any of the males. Hoon and Hoon (unpublished manuscript) compare male and female reports of sexual arousability using the Sexual Arousability Inventory (Hoon et al., 1976). Although this instrument was originally validated for use with females, the authors found when administering the inventory to groups of males and females that 13 of the 26 Sexual Arousability Inventory items could discriminate between the male and female groups. Males reported higher arousal to visual and genitally based activity 
items than females. Females reported more arousal than males to nongenitally based items. The females' resporses indicate that they favor the passive-recipient role, whereas males preferred the active role. There were no differences in report of subjective arousal between males and females in response to oral-genital items. Overall, the males reported higher levels of arousal than the females. In summary, it appears that there are differences in male versus female levels of objective and subjective arousal to a variety of stimuli. As Hoon and Hoon (unpubl) suggest, "men and women may be differentially aroused sexually when erotic stimuli are presented in different media forms, when experience with erotic activity portrayed changes, and when sex differences in tactile sensitivity at different body locations are considered" (p. 4). In adcition, it seems that most female reports of subjective arousal tend to comply with existing cultural and sex-role norms, however, female college students tend to prefer non-traditional female centered erotica. Although correlations between objective and subjective reports of arousal were significant, the relationship was less strong for the females.

\section{Arousal Patterns:}

Heterosexual, Homosexual \& Transsexual Males

Barr and Blaszczynski (1976) compared GSR and penile circumference changes of transsexual, homosexual and heterosexual males to erotic stimuli. Measures of perile circumference change indicate that homosexual and transsexual males are most aroused to homosexual stimuli, with the transsexual group showing more homosexual arousal than the 
homosexuai group. Both heterosexual and irarssexul males had a decrease in the penile arousal responst to the nonpreferred sex, male and female respectively. It was also found that the transsexuals had a larger GSR to female stimuli than did the homosexuals. These authors suggest that the male transsexual, (who believes he is in fact a female) is sexually interested in men and tends to crient toward females as a function of his interest in acquiring a female body. When comparing the self-report of sexual interest to an objective measure of sexual arousal in a group of 24 male transsexuals, Barr, Raphael and Hennessey (1974) found that penile circumference changes matched the self-report of exclusive sexual interest in males for 22 of the Ss. In addition, 20 of the Ss showed a decrease in the penile response to female stimuli. In summary, it seems that there is an exclusive homosexual orientation in most cases of the presurgical male transsexual. Furthermore, much as is the case with heterosexual males, the transsexual males appear to have a decrease in arousal to the nonpreferred sex.

$\underline{\text { Summary }}$

The studies mentioned above provide important information relevant to the study of sexual responsivity. Regarding the parameters of the sexual response, for most $\mathrm{Ss}$ there is a significant correlation between subjective and objective reports of arousal, and this relationship appears to be stronger for males than for females; the amount of sexual experience has no effect on physiological measures of arousal but the relationship between objective and subjective measures of sexual arousal is greater for individuals with more sexual experience; moving stimuli 
produce greater arousal responsez than still stimuli, maies can voluntarily suppress the erectile rasponse when instructed to do so, however, the suppression effect is only partial when in the presence of moving stimuli; and direct genital measures may be used to evaluate treatment outcome. Finally, regarding patterns of sexual arousal, it is suggested that both objective and subjective measures of sexual arousal can differentiate between a variety of populations.

Although much has been done in the last decade in the area of sexual research, numerous methodologies have been employed, hence, it is difficult, at best, to make cross-study comparisons. It is likely that many of the discrepant findings in the literature are a function of methodological differences. Differences in stimulus modality, stimulus content, as well as the means of assessing and interpreting subjective and objective arousal responses make it virtually impossible to compare sexual responsivity across individuals or across populations.

Some recent work done in our lab suggests that a device comparable to the female photoplythesmograph transducer probe may be used to discriminate sexual arousal from nonarousal states in males, an important finding for making more direct comparisons between male and female physiological arousal responses viable. A normal heterosexual male was shown one neucral and two erotic film sequences during which time physiological and subjective measures of sexual arousal were continuously recorded. Two devices were used simultaneously to collect objective indices of arousal; (1) a strain gauge, a widely used device which measures penile circumference changes (Barlow, Becker, Leitenberg $\xi$ 
Agras, i975), and (2) a surface phocoplythesmograpi designed to detect changes in surface blood puise amplitude. The photoplythesmograph was placed on the lateral dorsal aspect of the penile shafi, one centimeter distal to the medial axis, midway between the base of the penis and the glans. Much like the female probe, the surface photophythesmograph measures vasocongestive changes, in this case, changes in blood pulse amplitude of underlying surface penile tissue. It was predicted that measures of perile blood pulse amplitude change would be able to discriminate between nonaroused and aroused conditions since penile erection is mediated via increased penile vascularization (Weiss, 1972). Results of this investigation indicate that both the strain gauge and the surface photoplythesmograph were able to discriminate between arousal and nonarousal conditions when compared to each other as well as to the continuous measure of subjective arousal.

It was found that, in conjunction with the onset of erotic stimuli, there was first a very slight increase in penile circumference as measured by the strain gauge. Within approximately 8 seconds, there was a dramatic increase in penile vasocongestion as measured by the surface photoplysmograph. As penile circumference continued to increase to full erection, the heightened penile vasocongesion was maintained. When fuli erection was achieved, the penile vasocongestion measure dropped rapidly to below baseline levels. Throughout the maintenance phase of erection, the circumference remained stable and high while the penile vasocongestion remained below baseline level. When the erotic stimulus was withdrawn, there was an almost immediate increase in 
penile vasocongestion followed, whin approximately 8 seconds, by a steady decline in penile circumference. This pattern was replicated several times within this $S$, and is being looked at in other male Ss presently. Bancroft (19/2) suggests that erection "results from parasympathetically induced vasodilation, whereas emission and ejaculation together with the subsequent vasoconstriction and detumescence are functions of the sympathetic nervous system" (p. 247). It is suggested that the parasympathetically and sympatheticaliy innervated penile vasculature function differentially in the acquisition, maintenance and detumescence phases of the erectile response. During the acquisition phase, blood flows freely to both the skin and deeper cavernous tissues, Inediated via the sympathetic and parasympathetic vasculature respectively. Upon acquisition of a full erection, the sympathetically innervated vasculature in the penile skin shut down, shunting the blood from the surface tissue to the vascular spaces in the corpora cavernosa and the corpus spongiosum. With the offset of erotic stimulation, the influence of the sympathetic vasculature is reinstated, causing a marked increase in surface blood pulse amplitude which immediately precedes penile detumescence. Although not relevant to the purposes of the proposed study, this finding may be of important clinical significance by providing a method for establishing differential diagnosis of reflexogenic versus psychogenic sexual dysfunction in males.

Insert Fig. 5 about here 
For the purposes of the pronosed study, the above mentioned findings are extremely important. The ability to detect changes in vascularization of surface penile tissue associated with the presence or absence of erotic stimuli provides the researcher or clinician with a measure of male sexial arousal which is more directiy comparabie to measures of female arousal, making comparisons between these groups possible. It is possible that the surface photoplythesmograph would provide measures of the onset, offset, and magnitude of the sexual response in males which would be equivalent in character to the arousal response measured in İemales.

The following study is an attempt to investigate and compare the physiological and cognitive arousal patterns of normal heterosexual males and normal heterosexual females. By working within a controlled research paradigm, patterns of sexual responding within each group may be suggested and between group comparisons can be made. In response to Barlow's (1977) suggestion, that sexual responding may be considered to occupy 3 response domains (verbal, behavioral and physiological), selfreport, behavioral and physiological measures are used.

\section{$\underline{\text { Subjects }}$}

Group 1

One group of Ss were normal heterosexual female volunteers $(n=8)$. Ss were graduate and undergraduate students from the University of Rhode Island and Brown University. Each potential $S$ was rated on the Kinsey Scale (Kinsey, Pomeroy \& Martin, 1948). Only those receiving a score of 
"o", indicating exclusive heterosexual sexual orientaiion, were included in the study.

Group 2

A second group of $S s$ included normal heterosexual male volunteers $(n=8)$. Male Ss were solicited from the same populations as the female Ss. Again, only thase Ss who received a score of "O" on the Kinsey Scale were included in the study.

To insure the lack of any psychiatric disturbance, all Ss in each group underwent an interview preceding the experimental session. A qualified member of the research team administered the interviews. A potential $S$ in either group who reported an aversion to explicit sexual material was not included in the study. All Ss were paid ten dollars for their participation.

\section{Measures}

Behavioral measures of sex-role typical behavior, self-report measures of sexua1 behavior and sexual arousal, and physiological measures of arousal were taken.

\section{Behavioral Measures of Sex-Role Behavior}

Sex roles may be viewed as multidimensional constructs. Genderspecific motor behavior represents one dimension of this construct. The Barlow et al. (1973) Masculinity/Feminity Behavioral Rating Scale is designed to discriminate sex-role stereotypic sitting, standing and walking behaviors. This instrument was employed to ascertain the extent to which eacri $S$ emitted characteristic sex-role motor behaviors. This 
measure was taken surrepticionsiy by a rater trained in it's use. The rater was seated in the receptior area outside of the experimental room. Each $S$ was asked to wait in the reception area for three minutes prior to being brought into the experimental room. During the three minutes, the rater completed the Masculinity/Feminity Behavioral Rating Scale.

\section{Subjective Measures}

The following subjective assessment procedures were used.

1. The BEM (1974) Sex-Role Inventory was administered to determine the extent to which each $S$ viewed him-or herself in terms of a particular sex-role stereotype.

2. Bentler's scales of sexual behavior (1968a; 1968b) were used to gather information regarding the extent of previous sexual experience. The female Ss completed only the female form. The male Ss completed only the male form. Bentler provides data to support the validity and internal consistency of these two scales. 3. To accumulate data regarding patterns of sexual arousal as well as attitudes regarding various sexual behaviors, the Sexual Arousability Inventory (Hoon et al., 1976), was administered. There are data to support the reliability and validity of this scale for use with females, and some preliminary work has been done (Hoon \& Hoon, unpublished manuscript) suggesting that it may also be valid for use with males.

4. Barlow (1977) and Wincze et a1. (1977) report at least moderate correlations between objective and subjective measures of sexual arousal in normal populations. A continuous measure of subjective 
arousa! was recorded using the Cognitive Lever. This subjective measure consists of a potentiometer driven by a mechanical lever so that it changes resistance according to where the lever is placed. The lever swings through approximately a 90 -degree arc and is mounted on a specially built tabie, so that each $S$ can operate the lever comfortably and effortlessly with one hand, while reclining. Each $S$ is given prior instructions on how to use the lever and had a chance to practice and experience what it feels like to move the lever completely forward and back. The lever swings through a metal arc scale calibrated from 1 to 10 , which each $S$ inspected before the experiment began. A lantern battery is connected across the potentiometer, so that voltage drop is produced which is proportional to the location of the lever in it's range. This voltage differential drives a Grass 7-DAE Driver Amplifier so that millimeters of pen deflection correspond in a linear manner to the position of the lever in it's range.

5. Attitudinal ratings of "pleasantness" were collected using a 7-point Likert scale following each stimulus presentation. This procedure is described by Mavissakalian et al. (1975).

6. Subjective ratings of "percent of sexual arousal" experienced were collected following each stimulus presentation. Each $S$ was asked to report on a scale from 0 to 100 the amount of sexual arousal he/she experienced during the preceding film. 
Physiological Measures of Arousal

Early work cone by Masters urd Johnson Suggests that vasocongestion of genetalia is the flrst indicari of sexua? arousal in both males and females. Zuckerman (1971) has suggested that the physioiogical measures of sexual arousal which provide the highest discriminate validity are direct genital measures. For the purposes of this study, an objective measure of each S's sexual arousal response was acquired by measuring changes in genital vasocongestion.

The Geer et al. (1974) vaginal photoplythesmograph transducer (probe) was used to measure vaginal vasocongestion changes on the surface of the vaginal wall for the female Ss. When used in conjunction with Grass Pre-Amplifier Model 7P1 and Grass Physiograph Model RPS7C8, changes in vaginal vasocongestion were recorded which provide a reliable and valid measure of sexual arousal (Geer et al., 1974; wincze et al., 1977). The vaginal photoplythesmograph consists of an infrared light source and a phototransistor detector cell housed in a clear acrylic probe. The probe is approximately $1 / 2$ inch in diameter and $13 / 4$ inches in length. The probe measures the amount of light reflected from the vaginal wall. Hence, the greater the vasocongestion, the less reflectance, which when recorded is translated into increased arousal. Insertion of the probe elicits no more arousal than insertion of a tampon, therefore, does not confound the physiological recordings of arousal.

The use of the probe as a reliable and valid measure of sexual arousal has been demonstrated in several studies of normal and dysfunctional females (Wincze et al., 1976; Wincze et a1., 1977; Heiman, 1975). 
The female Ss were instructer to insert the probe in private. Placement of the probe was manipuated ujizl c ciear signal was received. The connecting wire was secured to the S's right thigh. This helps to eliminate movement artifact. A female investigator checked to insure that the probe had been inserted and secured correctly. Throughout the experimental session the $S$ was seated in a comfortable reclining chair. Each $S$ was covered with a light shielding blanket to eliminate the effect of light present in the experimental room upon the physiological measures. A constant room temperature was maintained for all Ss. The probe was sterilized prior to each S's use. The sterilization procedure involves soaking the probe in a germicidal Cidex solution for 20 minutes, rinsing the probe in cold water, wrapping the probe in a sterile gauze pad, and storing the probe in a sterilized container.

In a recent review of devices designed to quantify the male sexual response, Abel and Blanchard (1976) discuss the efficacy of the strain gauge for gathering reliable and valid measures of penile circumference changes which accompany sexual arousal. In addition to using the frequantly used strain gauge (Bariow et al., 1970), to measure penile circumference changes for the male Ss, a Grass Model 10022 surface photoplythesmograph was used to measure penile vasocongestion changes, providing a measure comparable to that of the females. The male Ss were instructed as to the placement of the photoplythesmograph and the strain gauge by a male investigator. After having placed these two instruments in private, a male investigator checked to insure proper placement. As with the female Ss, placement of the photoplythesmograph was manipulated until a clear signal was received. The connecting wires 
were secured with surgical. tape to the $S: s$ thigh to eliminate movement artifact. The remainder ci the experimental sessior was identical for ail Ss.

Heart rate frequency was monitored across ali experimental conditions using a Grass Photoeiectric Pulse Transducer Model FTTL and a Grass Preamplifier Tachograph Modei 7P4F. The transducer was clipped to the S'S right earlobe. Although many extant studies of sexual arousal have reported collecting heart rate data, none have demonstrated that there are changes in heart rate associated with changes in sexual arousal. For the purposes of this study, heart rate data were used only as an indicant of nonspecific arousal. This was particularly useful during the pre-experimental adaptation period. For example, if, for a given $S$, an elevated heart rate was observed during the adaptation period, the duration of the adaptation period was increased to insure a stable arousal state prior to the beginning of the experimental session.

Each of the self-report and behavioral measures were administered immediately prior to the experimental session. Vasocongestion, heart rate and report of subjective arousal were moritored throughout the entire experimental session. Ratings of "pleasantness" and percentage of sexual arousal were collected one minute following each stimulus presentation.

\section{Experimental Design}

A multi-group multi-factor $6 \times 5$ repeated measures design was employed. Group I consisted of eignt normal heterosexual females. Group 2 consisted of eight normal heterosexual males. The first factor consisted of six 4-minute videotaped film sequences. The six stimulus 
sequences were: (1) no film, taseline; (2) a levtral film portraying scenes of the coast of nova Scotia; (3) a Heterosexual Activity film, a male/fenale couple engaging in explicit sexual activity; (4) a Homosexual Activity film, two males engaging in explicit sexual activity; and (5) a Lesbian Activity film, two females engaging in explicit sexual activity; and (6) a Group Sex film, a group of males and females engaging in explicit sexual activity. Previous research (Wincze et al., 1977; Hioon et al., 1976; Mavissakalian et al., 1975) has demonstrated that film sequences representing these content areas reliably produce changes in male and femaie arousal responses. Abel et al. (1975), Freund, Langevin, Zajac, Steiner, and Zajac (1974) and Sanford, (1974) have shown that when compared to slides or audiotapes, moving stimuli elicit the greatest changes in the sexual arousal response, and, therefore, may be considered to be the stimulus modality of choice.

\section{Experimental Session}

Each $S$ was run individually. The physiological measures and the cognitive lever were fully explained to each $\mathrm{S}$ by a same-sex investigator. See appendix A for instructions to Ss. For all Ss, following the instruction period, the investigator left the room. At this time, the $S$ inserted the probe (in the case of females) or connected the strain gauge and the photoplythesmograph (males). When the S signaled that the instrument had been attached, the investigator reentered the room and checked to insure proper placement. At this time, the investigator connected the photoelectric pulse transducer to the S's right earlobe and a ground electrode to the s's right thigh. The investigator then 
told the $S$ that following each of the film sequences which the $S$ was about to see, he/she would be asked to rate their degree of "pieasantness." The investigator then thoroughly explained the use of the 7 -point rating scale. Each $S$ was also told that following each film, he'she would be asked to report his/her overall level of sexual arousal during the preceding film. The investigator then answered any questions and left the room. All further communication between the $S$ and investigator was via an intercom connecting the experimental room to the adjacent lab.

A 15-minute adaptation period preceded the experimental session. If a S's physiological measures had not stabilized at the conclusion of 15 minutes, the adaptation period was extended until such time as they had. Data accumulated during the last 4 minutes of the adaptation period provided baseline measures of each dependent variable. Following the adaptation period, the word "Relax" appeared on the screen, followed by a travelogue sequence. These stimuli were presented for 2 minutes each to control for the orienting response. Upon offset of the travelogue, each of the 5 experimental stimuli were presented and then withdrawn in a predetermined randon order. Prior to the initiation of the experiment, 20 random stimulus orders were determined. Ss from each group were randomly assigned to one of the stimulus orders. Each stimulus was presented for a 4 minute interval. One minute following the offset of each stimulus, the $S$ was asked to "please rate the pleasantness of the film you have just viewed." When the $S$ had responded, he/she was asked "On a scale from 0 to 100, how sexually aroused were you during that film?" Between each stimulus presentation, there was a 3 minute return to baseline inter-trial jnterval. Inmediately following the 
experimertal session, each $S$ was debrieted. During the debriefing, the $S$ was first asked a series of questions from a debrifing questionnaire (see Appendix B). Wner the $S$ had completed the questionnaire, the investigator answered any questions the $S$ may have had. At this time, the $S$ was also told that unobtrusive ratings of his/her motor behavior were taken prior to the experimental session.

Data Sampling

Objective and subjective arousal data were sampled every 20 seconds across the baseline and stimulus presentation periods. The photoplythesmograph transducer probe and the surface photoplythesmograph signals were integrated using a Grass 7 P3 Integrator. Changes in the amplitude of the signal reflect changes in the sexual response. Each data point was reported as distance in milimeters from a zero baseline. Differences between basal measures and evoked measures provided indices of change in sexual responding. The linear output produced by the cognitive lever (continuous subjective arousal) provided measures of pen deflection, where each $.5 \mathrm{~mm}$ increment represents 1 scale point on the cognitive lever. Subjective ratings range from "0," no arousal, to "10," maximum arousal. All data were reduced by hand. Reliability was estimated by having a second rater score $10 \%$ of the data for each dependent measure. Reliability was estimated to exceed .999.

Data Analysis

Separate 2-way ANOVAS with Repeated Measures on the second factor for each dependent variable were performed. Both between and within 
group differences were anifyed using $F$ tests and Newan-heuls tests, respectively. To assess the correlation betweer subjective and objective measures of sexual arousal, Pearson's correlation coefficients were computed for each individual s's data. In an attempt to determine the relationship between objective and subjective measures of arousal for each group, correlation coefficients were computed using the mean values of each individual S's data.

Although it may be argued that the various physiological data and the subjective data have different scaling properties and ranges, all of the dependent measures being used have quantifiable ranges. Turskey (1977) has defended the use of parametric statistical analysis in comparing physiological and subjective data. He has suggested observing a conservative (.01) level of significance for such data.

$\underline{\text { Results }}$

Separate 2-Way ANOVAS with repeated measures on the second factor were computed for the male and female data. Analysis were performed for each of the two male physiological measures (penile circumference and penile vasocongestion) and the female physiological measure (vaginal vasocongestion). The analysis was also performed on the continuous subjective arousal data separately for each sex. The first factor was a condition factor which consisted of six levels representing each of the four minute stimulus film sequences: baseline, neutral, heterosexual, homosexual, lesbian and group. The second factor was a time factor which consisted of five 20 second intervals for each of the six stimulus conditions. 
Aralysis for Males

Results of the $6 \times 5$ ANONA incicate significant main effects for the stimulus condition $(E(7,35)=11.93, \mathrm{p}<.001)$, for time $(F(7,28)=$ $9.53, p<.001)$ and for the interaction of condition by time $(F(7,140)=$ 2.10, $p<.01$ ) for the male penile circumference data.

Insert Tables $1 \& 2$ About Here

Ir order to interpret the significant interaction, simpie effects tests were performed for stimulus conditions at each of the five levels of time. Significant differences $(p<.01)$ were found between stimulus conditions at each of the levels of time. In order to determine the source of these significant differences, individual Newman-Keuls tests were performed at each level of time. A summary of the Newman-Keuls analysis for the male penile circumference data is presented in table 3 .

Insert Table 3 About Here

Results of this analysis indicate that at Time 1 the Baseline condition produced significantly $(p<.01)$ less change in penile circumference than either the Lesbian or Group conditions. The change, as may be seen in the table of means, under the Lesbian and Group conditions was in the direction of increasing sexual arousal. Also, the Neutral condition produced significantly $(\mathrm{p}<.01)$ less change in penile circumference than the Group condition. For stimulus condition at Times 2,3,4, and 5, the 
analysis indicate thet the Beseline, Nevtral and Homostial conditions produced significantiy less change in perile circumference than did the Heterosexual, Lesbian and Group conditions. No significant differences were found between the Baseline, Neutral and Homosexual conditions or between the Heterosexual, Lesbian and Group concitions. The mean data indicate that there were increases in sexual arousal in the presence of the Heterosexual, Lesbian and Group conditions.

\section{Insert Figure 1 About Here}

Figure 1 presents a comparison of each of the stimulus conditions for each of the five levels of time for the male penile circumference data.

A $6 \times 5$ ANOVA for the male penile vasocongestion data was performed. No significant main effect for condition or time and no significant interaction was found.

Insert Tables $4 \& 5$ About Here

Although no significant main or interaction effects were found for the penile vasocongestion data, examination of the raw data suggested that changes in penile vasocongestion seemed to accompany the onset and the offset of higher levels of sexual arousal. Since changes in the penile vasocongestion data may have been masked by including all of the low level arousal data in the original analysis, a cursory examination 
For each individual male subject, the maximut sexual arousal response recorded by the strain gauge periale circimference measure) was determined. The penile circumference data for this particular response was then broken down into three phases; the acquisition phase beginning with the first increase in penile circumference above baseline and continuing until the maximum penile circumference response was recorded), the maintenance phase (beginning with the next data point following the acquisition phase and continuing until three consective data points indicated a decrease in penile circumference), and the detumescence phase (beginning at the end of the maintenance phase and continuing until return to baseline). Using this three phase delineation, the concurrent penile vasocongestion data were reanalyzed in a $3 \times 6$ ArovA with repeated measures across the second (time) factor. Again, no significant differences were found between the phases of the erectile response for the penile vasocongestion data.

Insert Tables $6 \& 7$ About Here

Results of a $6 \times 5$ ANOVA for the male subjective arousai data indicate significant main effects for condition $(F(7,35)=13.42$, $\mathrm{p}<.001)$, and time $(\mathrm{F}(7,28)=7.09, \mathrm{p}<.001)$ and a significant inter action effect $(F(7,140)=5.37, p<.001)$. 
In order to interpret the significant interaction, Simple Effects tests for condition at each of the five levels of tine were performed. Significant effects $(p<.01)$ for conditions at each of the levels of time were found. The sumary data for the Newman-Keuls analysis, done to determine the source of these significant findings, of the male subjective arousal data are presented in Table 10 .

Insert Table 10 About Here

Results of this analysis indicate that for condition at Time 1 the Baseline, Neutral anà Homosexual conditions produced significantly $(p<.01)$ less reported subjective arousal than did the Lesbian condition. No other significant differences existed at Time 1. For condition at Times 2,3,4, and 5, significantly $(p<.01)$ less subjective arousal was reported under the Baseline, Neutral and Homosexual conditions than under the Heterosexual, Lesbian and Group conditions. In addition, at Time 4 the Heterosexual and Lesbian conditions produced significantly less subjective arousal than did the Group condition. There were no significant differences between the Heterosexual, Lesbian and Group conditions at Times $1,2,3$, and 5 . There were also no significant differences between the Baseline, Neutral and Homosexual conditions. The mean subjective arousal data indicate that the males reported increases in subjective arousal during the Heterosexual, Lesbian and Group conditions. 
Figure 2 presents a comparison of the stinuius conditions at each of the five levels of time fo: the male subjective arousal data.

\section{Aralysis for Females}

Results of the $6 \times 5$ ANOVA for the female vaginal vasocongestion data indicate a significant main effect for condition $(F(7,35)=2.81$, $p<.03$ ), but no significant effects for time or the interaction of condition and time.

\section{Insert Tables 11 G 12 About Here}

In order to interpret the source of differences between stimulus conditions, a Newman-Keuls analysis was done. Results of the Newman-Keuls analysis indicate that the Neutral and Baseline conditions produced significantly $(p<.01)$ less change in vaginal vasocongestion than did the Heterosexual and Group conditions. No differences between the Baseline, Neutral, Homosexual and Lesbian conditions were found.

Insert Table 13 About Here

Examination of the meaned vaginal vasocongestion data indicates that heightened levels of sexual arousal occurred only under the Heterosexual and Group stimulus conditions.

A $6 \times 5$ ANOVA for the female subjective arousal data was performed. Results of this analysis indicate significant main effects for condition 
$\left(\frac{r}{1}(7,55)=6.25, p<.001\right)$ and time $(F(7,28)=5.77, p<.002)$ and for the interaction of condition and time $(F(7,140)=2.13,0<.006)$.

Insert Tables 14 \& 15 About Here

In order to interpret the interaction, Simple Effects tests were performed for conditions at each of the five levels of time. Results of these tests show significant $(p<.01$ ) effects for condition at Times 2 , 3,4 and 5. Newman-keuls tests for condition at these times were performed to determine the source of the significant differences. These data are presented in Table 16.

\section{Insert Table 16 About Here}

The results of these analyses indicate that for condition at Time 2 the Baseline and Neutral conditions produced significantly $(\mathrm{p}<.01)$ less reported subjective arousal than did the Group and Heterosexual conditions. No significant differences were found between the Group and Heterosexual conditions or between the Baseline, Neutral, Homosexual and Lesbian conditions. At Times 3,4 and 5 , there was significantly $(\mathrm{p}<.01)$ less reported subjective arousal for the Baseline and Neutral than for the Lesbian, Group and Heterosexual conditions. In addition, at Times 3 and 5 there was significantly less $(p<.01)$ subjective arousal under the Homosexual condition than under the Heterosexual condition. At Time 5 there was also less subjective arousal recorded under the Homosexual 
condition than under the Heterosexuai condition. At Time 5 there was also less subjective arousai recorded under the Homosexual condition than under the Lesbian condition. There were no differences in subjective arousal between the Baseline ard Neutral stimulus conditions. Examination for the mean subjective arousal data indicates that the females reported heightened levels of subjective arousal during the Lesbian, Heterosexual and Group stimulus conditions.

Insert Figure 3 About Here

Figure 3 presents the meaned subjective arousal data for the female subjects. This figure illustrates the reported differential levels of subjective arousal under the experimental stimulus conditions.

Comparison of Objective and Subjective Measures

To determine the relationships between the physiological and subjective measures of sexual arousal, Pearson Produce Moment Correlation Coefficients were computed for each individual subject's data. These data are presented in Table 17.

Insert Table 17 About Here

Males

A significant relationship between the two measures of physiological arousal, penile circumference and penile vasocongestion, was found for 
only two of the subjects $(r=.73 \& r=.48, p<.01)$. A significant relationship was found between the penile circumference and subjective arousal data for each of the 8 male subjects. The correlations ranged from $r=.58$ to $r=.94$. A significant relationship was found for three of the male subjects between their penile vasocongestion and subjective arousal data $(r=.43, r=.48, \& r=.54 .(p<.01))$.

Females

A significant relationship between the vaginal vasocongestion and subjective arousal measures of sexual arousal was found for 5 of the 8 female subjects. The correlations ranged from $r=.38$ to $r=.76$.

\section{Demographic Measures}

When comparing the attitudinal (BEM) and behavioral (Motor Behavior Checklist) measures of sex-role typcial behavior, it was found that for the male subjects there was $85 \%$ agreement on the male scales of these two measures and oilly $3 \%$ agreement on the female scales. For the female subjects, there was $8 \delta \%$ agreement on the male scales of the two measures and $90 \%$ agreement on the female scales. The males achieved a mean masculinity score on the BEM of 5.18 , and a mean feminity score of 4.56 . The normative scores for males on the BEM are 4.97 (Masculinity scale and 4.44 (feminity)(Bem, 1974). The females achieved a mean feminity score of 4.82 and a mean masculinity score of 4.84 , compared to the norms for females which are 5.01 (feminity) and 4.57 (masculinity). Both the males' and the females' BEM scores suggest that they have more andorgenous sex-role attitudes than one would expect of the general population. 
The mean scores for miajes and females on the Sexual Arousability Inventory are 94.38 and 75 , respectively. Althougl normative data for male responses on this inventory have not yet been publisined, the females scores in the 30 th percentile. Using the female norms, the males in this study scored in the 65 th percentile.

The mean score for males on the Bentler sexual experience inventory was 20.29. The mean score for females was 20.25. The norms, taken from Bentler's largest cross-validation samples, for males and females respectively are 19.37 and 13.27 , suggesting that these subjects have had more sexual experience than the average for the population upon which the norms are based.

\section{Discussion}

Male and Female Differential Patterns of Physiological Responding to Erotica:

The results of this study suggest that when normal heterosexual males and females view a variety of erotic film sequences they have discriminably different physiological sexual arousal patterns in reaction to these films. For the males, the highest levels of physiological arousal were observed in the presence of the group sex film sequence, followed by the lesbian and heterosexual films. Although some physiological arousal was detected in the presence of the homosexual film, it was significantly less than the arousal observed under the other three erotic film conditions. For the females, the highest levels of physiological arousal were observed also in the presence of the group sex film, followed by the heterosexual film sequence. When ordering the means for 
the erotic film conditions, it is interesting to compare the relative amounts of arousal produced by the different film sequences for the males and the females. The observed differences suggest that males and females have different patterns of physiological responsivity, that is, it appears that males and females are not equally aroused by the same erotic material. The erotic film conditions for the males are in the order: homosexual, heterosexual, lesbian and group sex (going from least to most arousing); compared to the females whose ascending order is homosexual, lesbian, heterosexual and group sex. It is interesting that for the males, high levels of sexual arousal occurred in the presence of opposite-sex homosexual activity (the lesbian film) whereas for the females, the lowest level of sexual arousal was observed during the presentation of the opposite-sex homosexual activity film (the male homosexual sequence). For both the males and the females, the highest levels of physiological arousal were observed in the presence of the group sex film, replicating the findings of Sintchak and Geer (1975) and Hoon, Wincze, and Hoon (1976).

A unique finding of this study is that the film depicting homosexual activity was the least physiologically arousing erotic film for both the males and the females. Until quite recently, the American Psychological Association has classified homosexuality as a disease. Furthermore, numerous legal and religious sanctions against homosexuality continue to exist. Given the negative social sanctions surrounding homosexual behavior, it is possible that heterosexual individuals observing this behavior consider it to be deviant. It may be that homosexual activity is at such a high level of social unacceptability (deviance) that it 
takes on an aversive rather than arousing function. In the present study, each subject was asked if any of the films were disturbing to him or her during a debriefing which took place immediately following the experimental session. Every one of the males reported that he found the homosexual film to be disturbing. These anecdotal data may lend some support to the notion that heterosexual males find male homosexual behavior to be extremely unacceptáble.

If social acceptability inhibits rather than facilitates sexual arousal, how, then, can the highly arousing function of the group sex film be explained? Perhaps, much like oral sex, group sex is viewed as an alternative heterosexual behavior which one may or may not choose to engage in. Group sex has never been described as a disease nor has it been as actively devalued by society as homosexual activity.

When heterosexual males and females are observing group sex activity, they may well be able to identify with the heterosexual behaviors they are viewing. However, it is unlikely that either the males or females would be able to identify with male homosexual behavior. If a heterosexual male were to engage in group sex activity and subsequently report his experience to his peers, it is likely that his peers would reinforce his behavior. However, if this male were to report having had a homosexual experience, it is indeed likely that his behavior would be punished. In other words, although strong social sanctions against male homosexual behavior appear to exist, this does not seem to be the case with group sex activity. 
Early reports of sexual behavior (Kinsey, Pomeroy, Martin \& Gebhart, (1953) suggest that there exists a high level of social condemnation of male homosexual behavior. The Kinsey reports list eleven reasons why male homosexual behavior is more strongly condemned than female homosexual behavior. The reasons inclucie such things as the Catholic Church's doctrine that to waste semen is a sin. It would seem that the effect of this type of taboo would be widespread and Iong lasting. It is also impcrtant to note that in spite of the comprehensiveness of the Kinsey reports, there is absolutely no reference to group sexual activity within them. Hence, it is possible that group sexual activity is a relatively recent social phenomenon and as such it may not be bound with a long history of social taboos.

It may be speculated that there exists some socially defined spectrum of socially acceptable and socially unacceptable behaviors, and that the level of social acceptability-unacceptability interacts with a particular behavior's arousability function. It is possible that there is some optimal level of social unacceptability for facilitating sexual arousal, and that anything which exceeds this level may be considered deviant and nonarousing. The group sex film may fall within the range of social unacceptability which enhances sexual arousal whereas the male homosexual film may be outside of this range and consequently be nonarousing. This may begin to explain why the group sex film was most arousing and the homosexual activity film least arousing for both the males and females. 
The highly arousing function of the Iesbiar film for the males is also interesting in light of this discussion. Even though the lesbian film depicts females engaged in homosexual behavior, it oroduced high levels of physiological arousal for the males. Although lesbianism is not a socially sanctioned behavior, it has not been devalued to the same extent as male homosexua] behavior. Again, as kinsey et al. (1955) point out, there is far more condemnation of male than of female homosexual behavior. And, in fact, a fair amount of the pornography produced for males does depict lesbian activity. Furthermore, there are a variety of acceptable behaviors available to females (e.g. holding hands in public, dancing together) which would be totally unacceptable for two males to engage in. As a result, individuals may be more used to observing two females interacting in a somewhat intimate fashion and consequently less likely to describe this behavior as deviant. To the extent that lesbian behavior is considered norm-breaking rather than deviant it is possible that lesbian activity falls within the range of social unacceptability which facilitates sexual arousal for males. When looking at the order of the means for the erotic film conditions, it is irteresting to note that the females displayed somewhat more physiological arousal while viewing the lesbian film than while viewing the male homosexual film. Since the homosexual film includes nude males' bodies, and since traditionally the assumption has been that nude male bodies are the preferred erotic material for heterosexual females, one might well predict the opposite results. It is possible that the homosexual film represents a class of behaviors which are more 
socially unacceptable to females than the behariors represented by the lesbian film. Again, it is possible that a complex relationship between social acceptability and sexual arousability may exist.

The findings that the group sex film which is female-centered and primarily female-oriented, produced high levels of arousal for both the males and the females; and, that the lesbian film produced significantly high levels of arousal for the males, are relevant to a discussion presented by Heiman (1977). Heiman reports that female-initiated, female-centered audiotapes produced significantly more arousal for females with a trend in that direction for males. Although Heiman's audiotape was of heterosexual rather than lesbian content, her suggestion that, "female-initiated, female-centered scripts may represent more specifically sexual and anti-role abiding expectations," (Heiman, 1977 , p. 15) thus producing high levels of arousal, may begin to explain the highly arousing function of these two film sequences. The norm-breaking or socially unacceptable nature of the content of the group sex and lesbian film sequences may be the factor responsible for their high arousability.

As early as 1953, Kinsey reported that neither heterosexual males nor females become erotically aroused in the presence of male homosexual sex. He also suggested that males become erotically aroused when viewing two females engaged in sexual activity but that females do not become aroused when viewing lesbian sex. The results of this study provide the clearest demonstration of these anecdotal data available in the literature to date. 
Another interesting point for comparison between males and females is the effect of time on physiological arousal. Although significant differences in both the males' and females' levels of physiological arousal while viewing the various erotic film sequences were observed, when looking at the time course of physiological sexual arousal, it was found that the males became increasingly aroused over time while viewing the erotic films, but, the females' sexual arousal did not increase over time. This suggests that the females reached and maintained their maximum level of physiological arousal for a particular film early in the presentation of that film sequence, whereas the males displayed a more gradual increase in physiological arousal throughout the presentation of a particular film sequence. There are two potential explanations for these findings. On the one hand, there may in fact be differences between males and females in the expression of physiological arousal over time, or, the differences found in this investigation may be a function of the different measures used to determine the presence of physiological arousal in males and females. Finally, Hoon and Hoon (1977) suggest that males may simply find erotic visual stimulation to be more arousing than do females.

The previous discussion has focused primarily upon the subjects as the source of differences in levels of sexual arousal achieved in the presence of the erotic stimuli. The characteristics of the erotic films also need to be considered. The film sequences used in this study were not matched for aesthetic quality, that is, the actors and actresses varied between the films and some of the films were in color and some in 
black and white. The problem of trying to match stimulus films exists for all researchers in this area, and may account for some of the disparate findings in the literature. Another point to be considered is the overall eroticism of the stimulus films for males versus females. Since pronography is produced primarily by and for males, it is likely to have less erotic value for females. Each of these variables may possibly be contributing to some of the differences observed in this study.

Differential Patterns of Subjective Responding to Erotica:

The findings of this study are consistent with those of other researchers who have suggested that males and females differ in their subjective responsiveness to sexual stimulation (Steele \& Walker, 1974; Heiman, 1975; and Izard \& Caplan, 1974). The focus of these studies has been upon differences between males and females in levels of responsiveness to sexual stimulation. In summary, their findings suggest that males report more subjective arousal to sexual stimuli than do their female counterparts. The next important step is to begin to look at the differential levels of reported sexual arousal in reaction to stimuli representing a variety of sexual behaviors. This information would provide a description of patterns of subjective sexual responsivity characteristic of males and females.

Results of this study suggest that groups of males and females emit differential patterns of subjective sexual responding. The males reported significantly high levels of subjective sexual arousal in the 
presence of the group sex, lesbian and hoterosexual film sequences (in that order). The females reported significantly high levels of subjective arousal during the heterosexual, lesbian and group sex films. Neither the males nor the females reported any subjective arousal during the homosexual film sequence.

Relationship Between Objective and Subjective Measures:

Conflicting reports regarding the relationship between subjective and physiological measures of sexual arousal have appeared in the literature. These disparate findings seem to appear most frequently when studying females. Geer et al. (1974) report finding no relationship between these two types of measures when females were exposed to erotic films. Wincze et al. (1977) report that 5 out of 6 females who showed high levels of vaginal vasocongestion while viewing a group sex film, failed to report any subjective arousal for this film sequence. On the other hand, Heiman (1977) and Henson et al. (1977) report finding significant relationships between objective and subjective measures of sexual arousal for females. Heiman (1975) presents data which suggest that at higher levels of sexual arousal there is a stronger relationship between the females' objective and subjective arousal measures. McConaghy (1969) reports finding poor relationships between males' subjective and physiological responses to erotica, however, Mavissakalian et al. (1975) and Heiman (1977) found significantly high relationships between these two measures of male sexual arousal. Overall, the literature appears to suggest that for most males there is a relatively high relationship between objective and subjective measures of sexual arousal, but that this 
relationship is far nore variable across females. The results of the present investigation support these finding.

There are several possible explanations for the lack of relationship between objective and subjective measures for some females.

Bancroft (1971) suggests that males may be using the degree of erectness of the penis when reporting their subjective arousal. Whereas males can use this as an overt feedback mechanism when estimating their subjective arousal, females must rely upon much more subtle physiological cues. During the debriefing which followed the experimental session in the current investigation, each subject was asked what information he or she was using to estimate subjective arousal. All of the females and 7 of the 8 males reported using both changes in their genetalia and cognitive changes to estimate their arousal. Since the male genital changes are far more apparent than the subtle changes which occur for females, it may be that the males had more information upon which to base their estimates. Also, it is possible that it was more difficult for the females to discriminate changes in low levels of sexual arousal than it was for the males to discriminate changes which were occurring at higher arousal levels.

It is interesting to note that for some of the females there was a marked discrepancy between their objective and subjective measures of arousal while viewing the group sex film. Although the physiological data indicate that the females acquired the highest levels of sexual arousal while viewing the group sex film, the females rated the heterosexual and 
lesbian films as being more subjectively arousing. It is possible that the females tended to rate their arousal in compliance with what they assumed society would sanction. These results replicate those presented by Wincze et a1. (1977).

Subjects:

Since the majority of studies of sexual behavior rely on a relatively small number of volunteer subjects, it is important to describe the demographic characteristics of the population. For example, potential subject differences across studies may account for some of the differences in relationships reported in the literature between objective and subjective measures of sexual arousal. The individuals who volunteered to participate in this study were all either undergraduate students or college graduates. Although there was an attempt to get volunteers who represented a range of age groups, the actual range was from 19 to 28 years, with a mean age of 22 years. It is also important to note that the subjects in this particular study expressed more androgenous sex-role attitudes and had more sexual experience than one would assume is representative of the population at large. It is quite possible that these variables could effect both objective and subjective measures of sexual arousal. Also, the fact that these people volunteered to participate in a study of sexual behavior may make them a unique group in the population. It is possible that since all of the subjects in this study were involved in academics that they were more in tune with changing social mores and perhaps more likely to admit being sexually aroused to a variety of films 
than one would expect to find in a cross section of the population. These factors might effect the relationship between objective and subjective measures of arousal. As with all clinically relevant issues, it is important to address these demographic variables. Although there is no apparent reason to believe that there are any physiological differences between these subjects and the population at large, care should be taken before generalizations are made.

The Surface Photoplythesmograph as a Measure of Arousal:

One of the purposes of this study was to assess the relative efficacy of the surface photoplythesmograph as a measure of male sexual arousal. Unfortunately, the surface photoplythesmograph, as a measure of male vasocongestive changes associated with sexual arousal, did not differentiate between arousal conditions. Several possibilities should be considered when reivewing these results.

Since the erectile response is mediated by changes in vascularization, it would seem reasonable to expect these changes to be measurable. While watching the data output there appeared to be changes in the surface photoplythesmograph signal. It is possible that although changes may have occurred, they were within such a constricted scale (on the order of 1 to $3 \mathrm{~mm}$ of pen deflection) that they were masked by signal noise. Improvements in the technology (e.g. adding a high frequency filter to eliminate the signal noise, amplifying the signal) may make it possible to discriminate changes in surface vasocongestion associated with arousal in future studies. In addition, the method of interpreting 
the photoplythesmograph signal may have been insensitive to changes in vascularization. Unlike the simple linear changes in penile circumference recordings, the characteristics of vascular changes are extremely complex. Rather than look at absolute changes in vasocongestion over time, it may be more appropriate in the future to look at specific parameters of the vasocongestion response. Some of the parameters which might be examined are; latency to maximum response, rate of decay of the signal, and latency to return to baseline. A fine grain analysis of this sort might provide important information about the hemodynamics of sexual arousal. Another point for consideration is again related to possible methodological problems. Since the vasocongestion response is an extremely rapid and subtle response, the 2 second hand sampling procedure may have been too gross a procedure to detect changes. Future investigations could use high speed computerized sampling to address this problem. The photoplythesmograph is designed to measure changes in vasocongestion of surface tissues. Perhaps the hypothesized sympathetically mediated surface changes account for only a small portion of the hemodynamic changes which occur during the erectile response prior to orgasm. It is possible that there were no marked surface changes at the levels of arousal observed. This would tend to support Montcastle's (1974) suggestion that the arousal response is predominantly parasympathetic in nature. With this in mind, future research might attempt to measure surface as well as deeper tissue changes in vasocongestion. When examining the raw data, it seems that changes in the surface vasocongestive response occurred at high levels of arousal. Again, subsequent 
investigations should attempt finer analysis of the surface photoplythesmograph data in the presence of masturbation to orgasm where arousal would be high.

The lack of significant findings regarding the utliity of the surface photoplythesmograph for measuring vascular changes associated with sexual arousal should not discourage future investigations in this area. The methodology and apparatus employed in this study were relatively crude. The hypothesis still seems viable. There is still very little data based understanding of human sexual responding, and particularly the hemodynamic mechanisms of the male erectile response.

\section{Future Directions}

Although the experimental design employed in the present study is similar to what has been used throughout the literature in this area, future research might be designed somewhat differently in a attempt to address some of the questions which have been raised. Erotic films could be rated on the dimension of social acceptability/nonacceptability. Subjects could be assessed to determine their liklihood of responding in a socially desirable direction. A larger and more representative sample of erotic stimulus material could be presented. In addition, several film sequences representing a single erotic content area might be presented in an attempt to establish the independence of eroticism for a particular form of sexual behavior. And ideally, all studies of sexual behavior would be replicated across a large representative segment of the population in an attempt to get representative descriptive information about the human sexual response. 
Technological advances shouid also be taken advantage of for the study of sexual behavior. For ganrle, the use of uitrasound presents a very interesting possibility for future examination of the human sexual response. Ar extremely sensitive ultrasonic device designed to detect changes in blood flow, called the doppler, has been used in medicine for approximately 10 years, but has never been used to assess sexual arousal.

The doppler could be used as an indirect measure of vascular changes associated with sexual arousal. In addition to having all of the potential uses discussed earlier with regard to the surface photoplythesmograph, the auditory nature of the doppler output could be used to provide ongoing feedback of sexual arousal. 
References

Abel, G., Barlow, D., Blanchard, E., \& Mavissakalian, M. Measurement of sexual arousal in male homosexuals: Effects of instructions and stimulus modality. Archives of Sexual Behavior, 4:623-629, 1975 .

Abel, G.G. $C$ Blanchard, E.B. The measurement and generation of sexual arousal in male sexual deviates. In M. Hersen, R.M. Eisler, \& P.M. Miller (Eds.), Progress in Behavior Modification, Vol. 2. New York: Academic Press, 1976.

Bancroft, J. The application of phychophysiological measures to the assessment and modification of sexual behavior. Behavior Research \& Therapy, 9:119-130, 1971.

Bancroft, J. The relationship between gender identity and sexual behavior: Some clinical aspects. In C. Oumsted and B.C. Taylor (Eds.). Gender Differences: Their Ontology and Significance. Edinburgh, Scotland: Shurchill-Livingston, 1972.

Barlow, D.H., Assessment of sexual behavior. In Ciminero A., Calhoun, K., Adams, H. (Eds.) Handbood of Behavioral Assessment. New York: John Wiley \& Sons, $197 \overline{7}$.

Barlow, D.H., Becker, R., Leitenberg, H., \& Agras, W.S. A mechanical strain gauge for recording penile circumference change. Journal of Applied Behavior Analysis, 6:355-367, 1973.

Barlow, D.H., Reynolds, E.H., E Agras, W.S. Gender identity change in a transsexual. Archives of General Psychiatry, 28:569-579, 1973.

Barr, R., Raphael, B. E Hennessey, N. Apparent heterosexuality in two male patients requesting change-of-sex operation. Archives of Sexual Behavior, 3:325-330, 1974 .

Barr, R. E Blazcyznski, A. Autonomic responses of transsexual and homosexual males to erotic film sequences. Archives of Sexual Behavior, 5:211-222, 1976.

Bem, S.L. The measurement of psychological androgyny. J. of Consulting E Clinical Psychology, 42:155-162, 1974.

Bentler, P.M. Heterosexual behavior assessment--I. Males. Behavior Research \& Therapy, 6:21-25, 1968. (a)

Bentler, P.M. Heterosexual behavior assessment--II. Females. Behavior Research \& Therapy, 6:27-30, 1968 . 
Conrad, S., G Wincze, J. Orgasmic reconditicning: A controlled study of its effects upon the sexual arousal and behavior of adult male homosexuals. Benavior Theray, 7:155-166, 1976.

Freund, K. Diagnostika homosexuality umuzu. Ceskosiovenska Psychiatrie, $53: 382-393,1957$.

Freund, K., Langevin, R., Zajac, Y., Steiner, B., \& Zajac, A. The transsexual syndrome in homosexual males. The $J$. of Nervous and Mental Disease, 158:145-153, 1974 .

Geer, J., Morokoff, P., \& Greenwood, P. Sexual arousal in women: The development of a measurement device for vaginal blood volume. Archives of Sexual Behavior, 3:559-564, 1974.

Green, R. E Money, J. Transsexualism and Sex Reassignment. Baltimore, Md.: Johns Hopkins Press, 1969.

Heiman, J. Use of the vaginal photoplythesmograph as a diagnostic and teatment device in female sexual dysfunction. Faper delivered at the Meeting of the American Psychological Association, Chicago, 1975 .

Heiman, J.R. A psychosiological exploration of sexual arousal patterns in females and males. Phychophysiology, 14:266-274, 1978 .

Hensen, D., Rubin, H., Hensen, C., \& Williams, J. Temperature change of the labia minora as an objective measure of femaie eroticism. J. of Behavior Therapy \& Experimental Psychiatry, 4:401-410, 1977.

Hoon, E. E Hoon, P. Sexual arousability: Differences between males and females on a self-report measure. Unpublished manuscript.

Hoon, E.F., \& Hoon, P. Differences between males and females on sex arousability inventory items. Paper presented at the 6 th Canadian Sex Research Forum, Calgary, September, 1977.

Hoon, P., Wincze, J., E Hoon, E. Physiological assessment of sexual arousal in women. Psychophysiology, 11:196-204, 1.976.

Izard, C., \& Caplan, S. Sex differences in emotional responses to erotic literature, J. of Consulting \& Clinical Psychology, 42:468, 1974.

Kinsey, A.C., Pomeroy, W.B. E Martin, C. Sexual Behavior in the Human Male. Philadelphia: W.B. Saunders, 1948.

Kinsey, A., Pomeroy, W., Martin, C. E Gebhard, P. Sexual Behavior in the Human Female. Philadelphia: K.B. Saunders, 1953. 
Masters, W. E Johnson, U. Human Sexual Response. Boston: Little, BrowI \& Company, 1966.

Mavissakalian, M., Blanchard, E., Abel, G., \& Barlow, D. Responses to complex erotic stimuli in homosexual and heterosexual males. British Journal of Psychiatry, 126:252-257, 1975.

Mountcastle, V.B. (Ed.) Medical Physiology, 13th ed., Vol. 1, St Louis: Mosby, 1974.

Mussen, P. E Scodel, A. The effects of sexual stimulation under varying conditions of TAT sexual responsiveness. J. of Consulting E Clinical Psychology, 19:10, 1955.

McConaghy, H. Subjective and perile phythesmographic responses following aversion therapy for homosexual impulses. British journal of Psychiatry, 115:723-730, 1969.

McConaghy, $\mathrm{N}$, Penile volume responses to moving and still pictures of male and female nudes. Archives of Sexual Behavior, 3:565-570, 1974.

Sanford, D.A. Patterns of sexual arousal in heterosexual males, The Journal of Sex Research, 10:150-155, 1974.

Sintchak, G. \& Geer, J.A. A vaginal plythesmograph system. Psychophysiology, 12:113-115, 1975 .

Steele, D.G. E Walker, C.E. Male and female differences in reaction to erotic stimuli as related to sexual adjustment. Archives of Sexual Behavior, 3:459-470, 1974.

Tursky, B. A psychophysical and psychophysiological approach to the assessment of the direction, intensity and meaning of a political attitude. Delivered as an Invited Address at the 17 th Annual Meeting of the Society for Psychophysiological Research, Philadelphia, Pa., 1977.

weiss, H.D. The physiology of human penile erection. J. of Internal Medicine, 76:121-133, 1977.

Wincze, P., Hoon, P. E Hoon, E. Sexual arousal in women: A comparison of cognitive and physiological responses by continuous measurement. Archives of Sexual Behavior, 6:121-133, 1977.

Zuckerman, M. Physiological measures of sexual arousal in the human. Phychological Bulletin, 75:297-329, 1971 . 
TABLE 1 Cell means and standard deviations for the male penile circumference data.

CONDITION TINE MEAN

$\begin{array}{lllll}\text { BSL } & 1 & 1 & 0.932 & 0.561 \\ \text { BSL } & 1 & 2 & 0.970 & 0.553 \\ \text { BSL } & 1 & 3 & 0.965 & 0.528 \\ \text { BSL } & 1 & 4 & 0.965 & 0.528 \\ \text { BSL } & 1 & 5 & 1.010 & 0.517 \\ \text { NEUTRAL } & 2 & 1 & 0.940 & 0.563 \\ \text { NEUTRAL } & 2 & 2 & 0.956 & 0.592 \\ \text { NEUTRAL } & 2 & 3 & 1.187 & 0.746 \\ \text { NEUTRAL } & 2 & 4 & 0.930 & 0.576 \\ \text { NEUTRAL } & 2 & 5 & 0.955 & 0.595 \\ \text { HETERO } & 3 & 1 & 1.667 & 1.162 \\ \text { HETERO } & 3 & 2 & 1.938 & 1.344 \\ \text { HETERO } & 3 & 3 & 2.277 & 1.525 \\ \text { HETERO } & 3 & 4 & 2.231 & 1.420 \\ \text { HETERO } & 3 & 5 & 2.258 & 1.388 \\ \text { HOMOSEX } & 4 & 1 & 1.180 & 0.436 \\ \text { HOMOSEX } & 4 & 2 & 1.285 & 0.547 \\ \text { HOMOSEX } & 4 & 3 & 1.310 & 0.641 \\ \text { HOMOSEX } & 4 & 4 & 1.348 & 0.765 \\ \text { HOMOSEX } & 4 & 5 & 1.287 & 0.579 \\ \text { LESBIAN } & 5 & 1 & 1.750 & 0.992 \\ \text { LESBIAN } & 5 & 2 & 2.117 & 1.365 \\ \text { LESBIAN } & 5 & 3 & 2.200 & 1.515 \\ \text { LESBIAN } & 5 & 4 & 2.398 & 1.538 \\ \text { LESBIAN } & 5 & 5 & 2.538 & 1.546 \\ \text { GROUP } & 6 & 2.192 & 1.294 \\ \text { GROUP } & 6 & 2.546 & 1.328 \\ \text { GROUP } & 6 & 2.521 & 1.179 \\ \text { GROUP } & 6 & 2.556 & 1.140 \\ \text { GROUP } & 6 & 5 & 1.153\end{array}$


TABLE 2 ANOVA summary table for male peniie circumference data ${ }^{*}(\mathrm{p}<.01)$

$\begin{array}{lcccc}\text { SOURCE } & \text { SS } & \text { DF } & \text { MS } & \text { F } \\ \text { Cond. } & 86.425 & 5 & 17.285 & 11.93^{*} \\ \text { Error (CS) } & 50.689 & 35 & 1.448 & \\ \text { Time } & 5.346 & 4 & .836 & 9.53^{*} \\ \text { Error (TS) } & 2.458 & 28 & .087 & \\ \text { Cond./Time } & 3.096 & 20 & .154 & 2.10^{*} \\ \text { Errox (CTS) } & 10.342 & 140 & .073 & \end{array}$


TABLE 3 Summary of Newman-Keuls analysis of nale penile circumference data for condition: Baseline(B), Neutral(N), Heterosexual(HE), Homosexual (HO), Lesbian(L), and Group Sex(G), at times 1 through $5 *(p<.01)$.

Time 1

B

N

$\mathrm{HO}$

HE

L

Time 2

B
$N$
HO
HE
L

Time 3

$\begin{array}{lllllll} & \text { B } & \text { N } & \text { HC } & \text { L } & \text { HE } & \text { G } \\ \text { B } & & & & * & * & * \\ \mathrm{~N} & & & & * & * & * \\ \mathrm{HO} & & & & * & * & *\end{array}$

L

HE

Time 4

N

B

$\mathrm{HO}$

$\mathrm{HE}$

L

Time 5

$\mathrm{N}$

B

$\mathrm{HO}$

HE

L
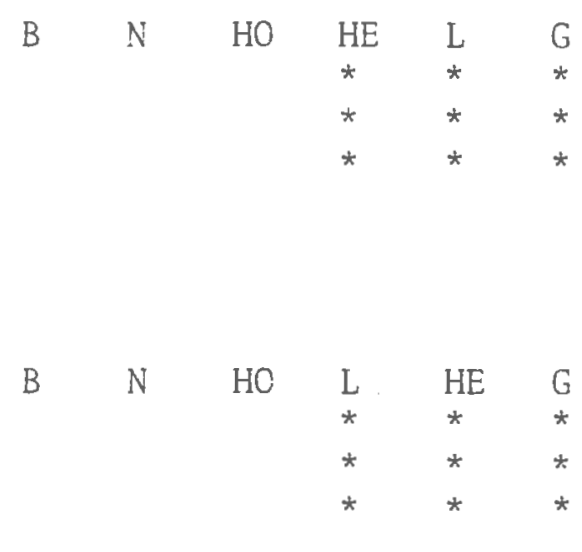
TABLE 4 Cell means and standard jeviations for the male penile vasocongestion data.

$\begin{array}{lll}\text { CONDITION TIME } & \text { MEAN }\end{array}$

$\begin{array}{lllll}\text { BSL } & 1 & 1 & 0.605 & 0.186 \\ \text { BSL } & 1 & 2 & 0.676 & 0.252 \\ \text { BSL } & 1 & 3 & 0.641 & 0.159 \\ \text { BSL } & 1 & 4 & 0.632 & 0.193 \\ \text { BSL } & 1 & 5 & 0.742 & 0.241 \\ \text { NEUTRAL } & 2 & 1 & 0.641 & 0.251 \\ \text { NEUTRAL } & 2 & 2 & 0.600 & 0.159 \\ \text { NEUTRAL } & 2 & 3 & 0.595 & 0.153 \\ \text { NEUTRAL } & 2 & 4 & 0.672 & 0.232 \\ \text { NEUTRAL } & 2 & 5 & 0.596 & 0.125 \\ \text { HETERO } & 3 & 1 & 0.662 & 0.250 \\ \text { HETERO } & 3 & 2 & 0.667 & 0.194 \\ \text { HETERO } & 3 & 3 & 0.583 & 0.156 \\ \text { HETERO } & 3 & 4 & 0.617 & 0.110 \\ \text { HETERO } & 3 & 5 & 0.607 & 0.142 \\ \text { HOMOSEX } & 4 & 1 & 0.711 & 0.192 \\ \text { HOMOSEX } & 4 & 2 & 0.642 & 0.166 \\ \text { HOMOSEX } & 4 & 3 & 0.688 & 0.181 \\ \text { HOMOSEX } & 4 & 4 & 0.598 & 0.110 \\ \text { HOMOSEX } & 4 & 5 & 0.653 & 0.195 \\ \text { LESBIAN } & 5 & 1 & 0.752 & 0.518 \\ \text { LESBIAN } & 5 & 2 & 0.768 & 0.422 \\ \text { LESBIAN } & 5 & 3 & 0.741 & 0.404 \\ \text { LESBIAN } & 5 & 4 & 0.716 & 0.307 \\ \text { LESBIAN } & 5 & 5 & 0.633 & 0.127 \\ \text { GROUP } & 6 & 1 & 0.698 & 0.160 \\ \text { GROUP } & 6 & 2 & 0.698 & 0.146 \\ \text { GROUP } & 6 & 3 & 0.750 & 0.315 \\ \text { GROUP } & 6 & 0.611 & 0.128 \\ \text { GROUP } & 6 & 0.706 & 0.255\end{array}$


TABLE 5 ANOVA sumnary table for the male penile vasocongestion data; condition and time factors * $(\mathrm{p}<.01)$.

\begin{tabular}{lcrcc} 
SOURCE & \multicolumn{1}{c}{ SS } & DF & MS & F \\
Cond. & .298 & 5 & .059 & .38 \\
Error (CS) & 5.447 & 35 & .155 & \\
Time & .044 & 4 & .011 & 1.42 \\
Error (TS) & .217 & 28 & .008 & \\
Cond./Time & .358 & 20 & .018 & 1.18 \\
Error (CTS) & 2.122 & 140 & .015 &
\end{tabular}


TABLE 6 Ceil means and standard deviations for the male perile vasocongestion data; comparison of the Acquisition, Maintainence, and Detumescence phases of the erectile response.

CONDITION

TIME

MEAN

$\mathrm{SD}$

$\begin{array}{ll}\text { ACQUI } & 1 \\ \text { ACQUI } & 1 \\ \text { ACQUI } & 1 \\ \text { ACQUI } & 1 \\ \text { ACQUI } & 1 \\ \text { ACQUI } & 1 \\ \text { MAINT } & 2 \\ \text { MAINT } & 2 \\ \text { MAINT } & 2 \\ \text { MAINT } & 2 \\ \text { MAINT } & 2 \\ \text { MAINT } & 2 \\ \text { DETUM } & 3 \\ \text { DETUM } & 3 \\ \text { DETUM } & 3 \\ \text { DETUM } & 3 \\ \text { DETUM } & 3 \\ \text { DETUM } & 3\end{array}$

1

1.181

0.918

1.193

1.546

0.675

0.208

0.593

0.165

0.568

0.103

0.700

0.302

0.612

0.115

0.687

0.157

0.593

0.086

0.743

0.154

0.656

0.275

0.662

0.182

0.950

0.916

0.868

0.543

0.793

0.360

0.706

0.285

0.800

0.250

3

0.731

0.246 
TABLE 7 ANOVA summary table for the $3 x$ male penile vasocongestion data $*(p<.01)$.

$\begin{array}{lcccc}\text { SOIRCE } & \text { SS } & \text { DF } & \text { MS } & \text { F } \\ \text { Cond. } & .763 & 2 & .382 & 1.30 \\ \text { Error (CS) } & 4.109 & 14 & .294 & \\ \text { Time } & 1.703 & 5 & .341 & 1.16 \\ \text { Error (TS) } & 10.271 & 35 & .293 & 1.32 \\ \text { Cond./Time } & 2.095 & 10 & .209 & \\ \text { Error (CTS) } & 11.098 & 70 & .159 & \end{array}$


TABLE 8 Cell means and standard deviations for the male continuous subiective arousal data.

$\begin{array}{llll}\text { CONDITION TIME MEAN } & \text { SD }\end{array}$

\begin{tabular}{|c|c|c|c|c|}
\hline BSL & 1 & 1 & 0.002 & 0.007 \\
\hline BSL & 1 & 2 & 0.006 & 0.017 \\
\hline BSL & 1 & 3 & 0.007 & 0.021 \\
\hline BSL & $I$ & 4 & 0.006 & 0.017 \\
\hline BSL & 1 & 5 & 0.012 & 0.035 \\
\hline BSL & $I$ & 6 & 0.012 & 0.035 \\
\hline NELITRA.L & 2 & 1 & 0.012 & 0.035 \\
\hline NEUTRAL & 2 & 2 & 0.012 & 0.035 \\
\hline NELTTRAL & 2 & 3 & 0.012 & 0.035 \\
\hline NEUTRAL & 2 & 4 & 0.012 & 0.035 \\
\hline INEUTRAL & 2 & 5 & 0.013 & 0.035 \\
\hline HETERO & 3 & 1 & 0.315 & 0.257 \\
\hline HETERO & 3 & 2 & 0.413 & 0.337 \\
\hline HETERO & $z$ & 3 & 0.546 & 0.366 \\
\hline HETERO & $z$ & 4 & 0.491 & 0.329 \\
\hline HETERO & 3 & 5 & 0.571 & 0.368 \\
\hline HOMOSEX & 4 & 1 & 0.078 & 0.150 \\
\hline HOMOSEX. & 4 & 2 & 0.077 & 0.135 \\
\hline HOMOSEX & 4 & 3 & 0.083 & 0.134 \\
\hline HOMOSE:X & 4 & 4 & 0.081 & 0.119 \\
\hline HOMOSEX & 4 & 5 & 0.091 & 0.339 \\
\hline LESBIAN & 5 & 1 & 0.427 & 0.339 \\
\hline LESE.IAN & 5 & 2 & 0.548 & 0.468 \\
\hline LESBIAN & 5 & 3 & 0.553 & 0.477 \\
\hline LESBIAN & 5 & 4 & 0.643 & 0.491 \\
\hline LESBIAN! & 5 & 5 & 0.713 & 0.501 \\
\hline GROUF' & 6 & 1 & 0.326 & 0.224 \\
\hline GROUP & 6 & 2 & 0.631 & 0.854 \\
\hline GROLIP & 6 & 3 & 0.825 & C. .395 \\
\hline GROUP & 6 & 4 & 0.895 & 0.478 \\
\hline GROUP & 6 & 5 & 0.586 & 0.271 \\
\hline
\end{tabular}


TABLE 9 ANOVt sumary tabie for male continuous subjective arcusal data * $(\mathrm{p}<.01)$.

\begin{tabular}{lrrrr} 
SOURCE & \multicolumn{1}{c}{ SS } & DF & MS & F \\
Cond. & 17.806 & 5 & 3.561 & $13.42^{*}$ \\
Error (CS) & 9.290 & 35 & .265 & \\
Tirre & .820 & 4 & .205 & $7.09 *$ \\
Error (TS) & .811 & 28 & .029 & \\
Cond./Time & 1.503 & 20 & .075 & $5.27 *$ \\
Errcr (CTS) & 1.959 & 140 & .014 &
\end{tabular}


TABLE 10 Results of Nermar-Keuls analysis of male subjective arousal data for condition: Baseline(B), Neltral(N), Heterosexual(HE), Homosexual(HO), Lesbian(L), and Grolip (G), at times 1 throligh $5 *(F<.01)$.

Time 1

B N HO HE G L

$B$

N

$\mathrm{HO}$

HE

G

Time 2

B

N

$\mathrm{HO}$

HE

L

Time 3

B

B N HO $\underset{*}{\mathrm{HE}} \underset{*}{\mathrm{~L}} \quad \mathrm{G}$

$N$

$\mathrm{HO}$

HE

L

Time 4

B

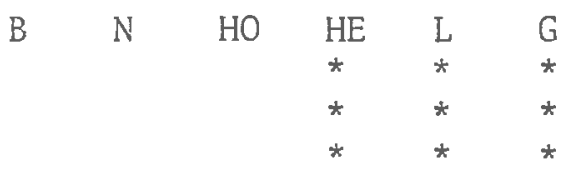

$\mathrm{N}$

HO

$\mathrm{HE}$

L

Time 5



$\mathrm{HE}$

G 
TABLE 11 Cell means and standard deviations for female vaginal vasocongestion data.

$\begin{array}{lll}\text { CONDITION TIME SEAN } & \text { SD }\end{array}$

$\begin{array}{lllll}\text { BSL } & 1 & 1 & 0.486 & 0.377 \\ \text { BSL } & 1 & 2 & 0.466 & 0.317 \\ \text { BSL } & 1 & 3 & 0.503 & 0.363 \\ \text { BSL } & 1 & 4 & 0.540 & 0.409 \\ \text { BSL } & 1 & 5 & 0.518 & 0.328 \\ \text { NEUTRAL } & 2 & 1 & 0.430 & 0.258 \\ \text { NEUTRAL } & 2 & 2 & 0.416 & 0.286 \\ \text { NEUTRAL } & 2 & 3 & 0.506 & 0.299 \\ \text { NEUTRAL } & 2 & 4 & 0.421 & 0.276 \\ \text { NEUTRAL } & 2 & 5 & 0.491 & 0.330 \\ \text { HETERO } & 3 & 1 & 0.711 & 0.348 \\ \text { HETERO } & 3 & 2 & 0.757 & 0.430 \\ \text { HETERO } & 3 & 3 & 0.837 & 0.476 \\ \text { HETERO } & 3 & 4 & 0.845 & 0.471 \\ \text { HETERO } & 3 & 5 & 0.818 & 0.500 \\ \text { HOMOSEX } & 4 & 1 & 0.618 & 0.254 \\ \text { HOMOSEX } & 4 & 2 & 0.535 & 0.299 \\ \text { HOMOSEX } & 4 & 3 & 0.562 & 0.262 \\ \text { HOMOSEX } & 4 & 4 & 0.592 & 0.287 \\ \text { HOMOSEX } & 4 & 5 & 0.535 & 0.267 \\ \text { LESBIAN } & 5 & 1 & 0.718 & 0.469 \\ \text { LESBIAN } & 5 & 2 & 0.605 & 0.349 \\ \text { LESBIAN } & 5 & 3 & 0.605 & 0.378 \\ \text { LESBIAN } & 5 & 4 & 0.658 & 0.399 \\ \text { LESBIAN } & 5 & 5 & 0.738 & 0.400 \\ \text { GROUP } & 6 & 1 & 0.705 & 0.450 \\ \text { GROUP } & 6 & 2 & 0.948 & 0.935 \\ \text { GROUP } & 6 & 3 & 0.771 & 0.452 \\ \text { GROUP } & 6 & 0.780 & 0.426 \\ \text { GROUP } & 6 & 0.771 & 0.481\end{array}$


TABLE 12 ANOVA summary table for female vaginal vasocongestion data.

$\begin{array}{lrrrr}\text { SOURCE } & \text { SS } & \text { DF } & \text { MS } & \text { F } \\ \text { Cond. } & 4.266 & 5 & .853 & 2.81 \text { * } \\ \text { Error (CS) } & 10.641 & 35 & .304 & .009 \\ \text { Time } & .036 & 4 & .334 & .02 \\ \text { Error (TS) } & .951 & 28 & .029 & .91 \text { * } \\ \text { Cond./Time } & .586 & 20 & .032 & \\ \text { Error (CTS) } & 4.507 & 140 & \end{array}$


TABLE 13 Results of Newman-keuls analysis of significant condition effect for female vaginal vasocongestion data * $(p \quad .01)$. Conditions are: Neutral(N), Baseline(B), Heterosexual(HE), Homosexual(HO), Lesbian(L), and Group (G).

N

N B HO L HE G

B

HO

L

$\mathrm{HE}$ 
TABLE 14 Cell means and stanaara deviations for female continuous subjective arousal data.

$\begin{array}{llll}\text { CONDITION TIME } & \text { MEAN }\end{array}$

$\begin{array}{lllll}\text { BSL } & 1 & 1 & 0.0 & 0.0 \\ \text { BSL } & 1 & 2 & 0.01 & 0.0 \\ \text { BSL } & 1 & 3 & 0.01 & 0.02 \\ \text { BSL } & 1 & 4 & 0.0 & 0.02 \\ \text { BSL } & 1 & 5 & 0.0 & 0.0 \\ \text { NEUTRAL } & 2 & 1 & 0.02 & 0.03 \\ \text { NEUTRAL } & 2 & 2 & 0.02 & 0.04 \\ \text { NEUTRAL } & 2 & 3 & 0.02 & 0.04 \\ \text { NEUTRAL } & 2 & 4 & 0.01 & 0.04 \\ \text { NEUTRAL } & 2 & 5 & 0.02 & 0.03 \\ \text { HETERO } & 3 & 1 & 0.46 & 0.59 \\ \text { HETERO } & 3 & 2 & 0.63 & 0.76 \\ \text { HETERO } & 3 & 3 & 0.76 & 0.75 \\ \text { HETERO } & 3 & 4 & 0.65 & 0.57 \\ \text { HETERO } & 3 & 5 & 0.77 & 0.52 \\ \text { HOMOSEX } & 4 & 1 & 0.27 & 0.34 \\ \text { HOMOSEX } & 4 & 2 & 0.28 & 0.31 \\ \text { HOMOSEX } & 4 & 3 & 0.30 & 0.31 \\ \text { HOMOSEX } & 4 & 4 & 0.27 & 0.18 \\ \text { HOMOSEX } & 4 & 5 & 0.22 & 0.15 \\ \text { LESBIAN } & 5 & 1 & 0.37 & 0.63 \\ \text { LESBIAN } & 5 & 2 & 0.34 & 0.45 \\ \text { LESBIAN } & 5 & 3 & 0.57 & 0.69 \\ \text { LESBIAN } & 5 & 4 & 0.71 & 0.77 \\ \text { LESBIAN } & 5 & 5 & 0.69 & 0.79 \\ \text { GROUP } & 6 & 1 & 0.34 & 0.39 \\ \text { GROUP } & 6 & 2 & 0.67 & 0.61 \\ \text { GROUP } & 6 & 3 & 0.59 & 0.52 \\ \text { GROUP } & 6 & 5 & 0.51 & 0.52 \\ \text { GROUP } & 6 & 54 & & \end{array}$


TABLE 15 ANOVA summary table ror o $x 5$ analysis of female subjective arousal data * $(\mathrm{p}<.01)$.

$\begin{array}{lrrrr}\text { SOURCE } & \text { SS } & \text { DF } & \text { MS } & \text { F } \\ \text { Cond. } & 15.505 & 5 & 3.101 & 6.25^{*} \\ \text { Error (CS) } & 17.355 & 35 & .496 & \\ \text { Time } & .582 & 4 & .145 & 5.77^{*} \\ \text { Error (TS) } & .706 & 28 & .025 & \\ \text { Cond./Time } & 1.175 & 20 & .059 & 2.13^{*} \\ \text { Error (CTS) } & 3.869 & 140 & .028 & \end{array}$


TABLE 16 Results of Newman-Keuls Analysis of female subjective arousal data for condition: Baseiine(B), Neutral(N), Heterosexual (HE), Homosexual (HO), Lesbian(L), Group Sex(G), at times 2 through $5 *(\mathrm{p}<.01)$.

Time 2

$\mathrm{B}$

B N HO L $\quad$ G HE

$\mathrm{HO}$

L

G

Time 3

B

N

HO

L

G

Time 4

$\begin{array}{lllllll} & B & N & H O & G & H E & L \\ B & & & & * & * & * \\ N & & & & * & * & *\end{array}$

$\mathrm{HO}$

G

HE

Time 5

B

B $N$ HO G I HE

N

$\mathrm{HO}$

B N HO L G HE

* * *

* $\quad * \quad *$

*

G

L 
TABLE 17 Summary of individual subjects pearson Correlation Coefficients for physiological (male; penile circumference (PC), \& penile vasocongestion (PV), female; vaginal vasocongestion (VV)) and subjective (SA) data ${ }^{*}=(\mathrm{p}<.01)$.

\begin{tabular}{|c|c|c|c|c|}
\hline \multirow{2}{*}{$\begin{array}{c}\text { Subject } \\
1\end{array}$} & $\mathrm{PCXPV}$ & $\mathrm{PCxSA}$ & PVxSA & VVxSA \\
\hline & -.21 & $.68^{*}$ & -.11 & \\
\hline 2 & .16 & $.80^{*}$ & $.43^{*}$ & \\
\hline 3 & -.25 & $.86^{*}$ & $-.48 *$ & \\
\hline थ 4 & .33 & $.94^{*}$ & .23 & \\
\hline$\sum_{z}$ & $-.73 *$ & $.69^{*}$ & $-.54 *$ & \\
\hline 6 & $.48 *$ & $.83 *$ & .29 & \\
\hline 7 & .33 & $.79^{*}$ & .15 & \\
\hline 8 & -.15 & $.72 *$ & -.28 & \\
\hline 1 & & & & -.12 \\
\hline 2 & & & & $.54^{*}$ \\
\hline 3 & & & & $.76^{*}$ \\
\hline$\stackrel{\mathscr{\Perp}}{\stackrel{\infty}{\sim}} 4$ & & & & $.52 *$ \\
\hline$\stackrel{\frac{\pi}{E}}{\Phi} 5$ & & & & $.48 *$ \\
\hline 6 & & & & -.33 \\
\hline 7 & & & & $.58 *$ \\
\hline 8 & & & & .30 \\
\hline
\end{tabular}




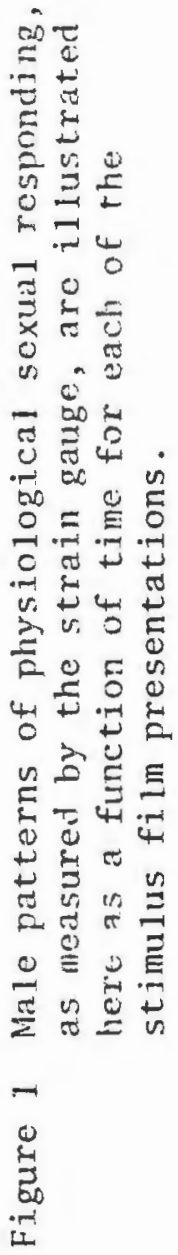




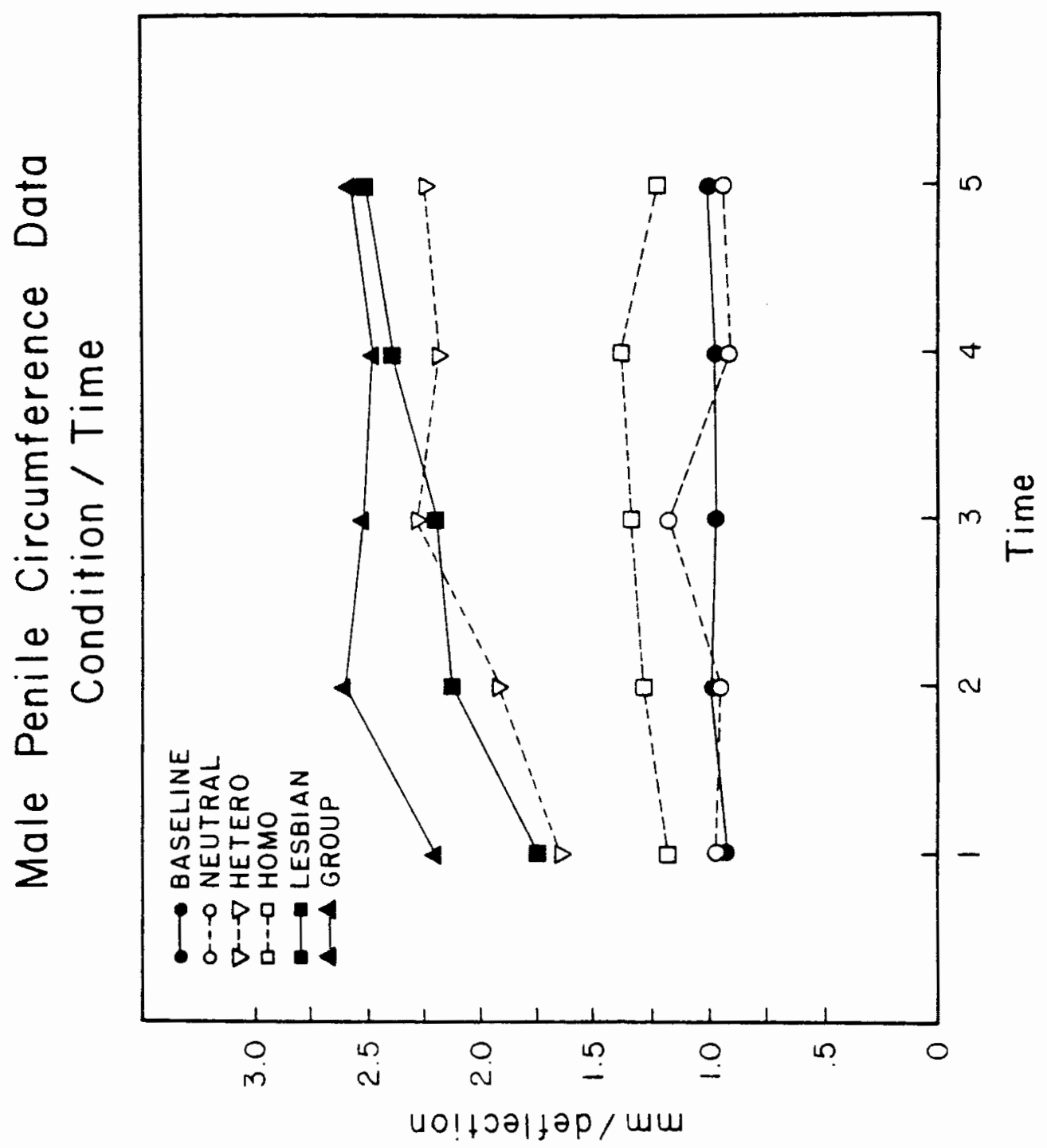




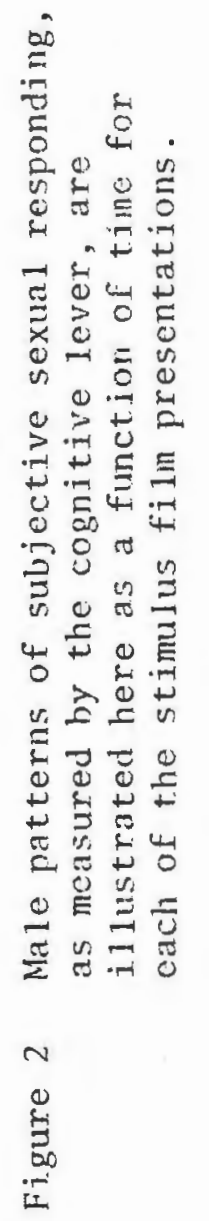




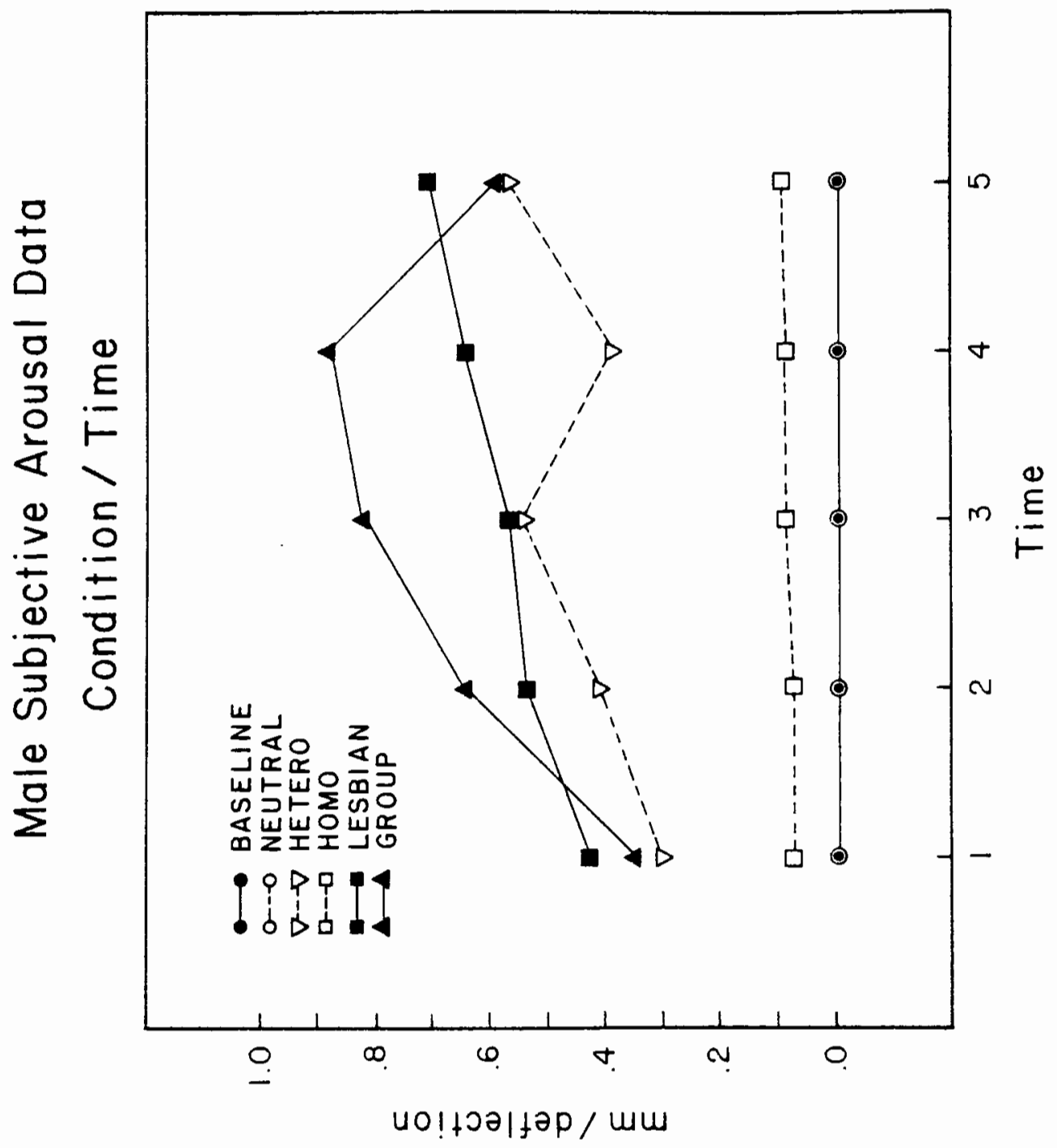




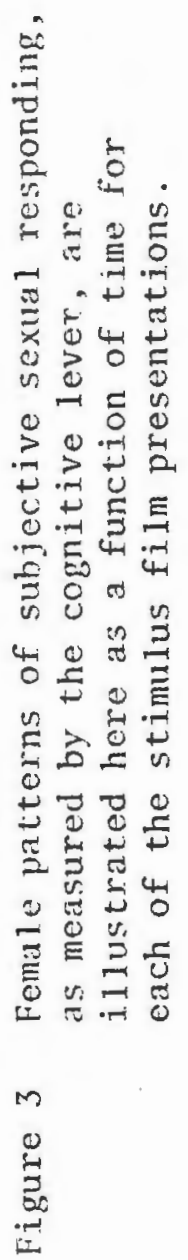









$$
1
$$




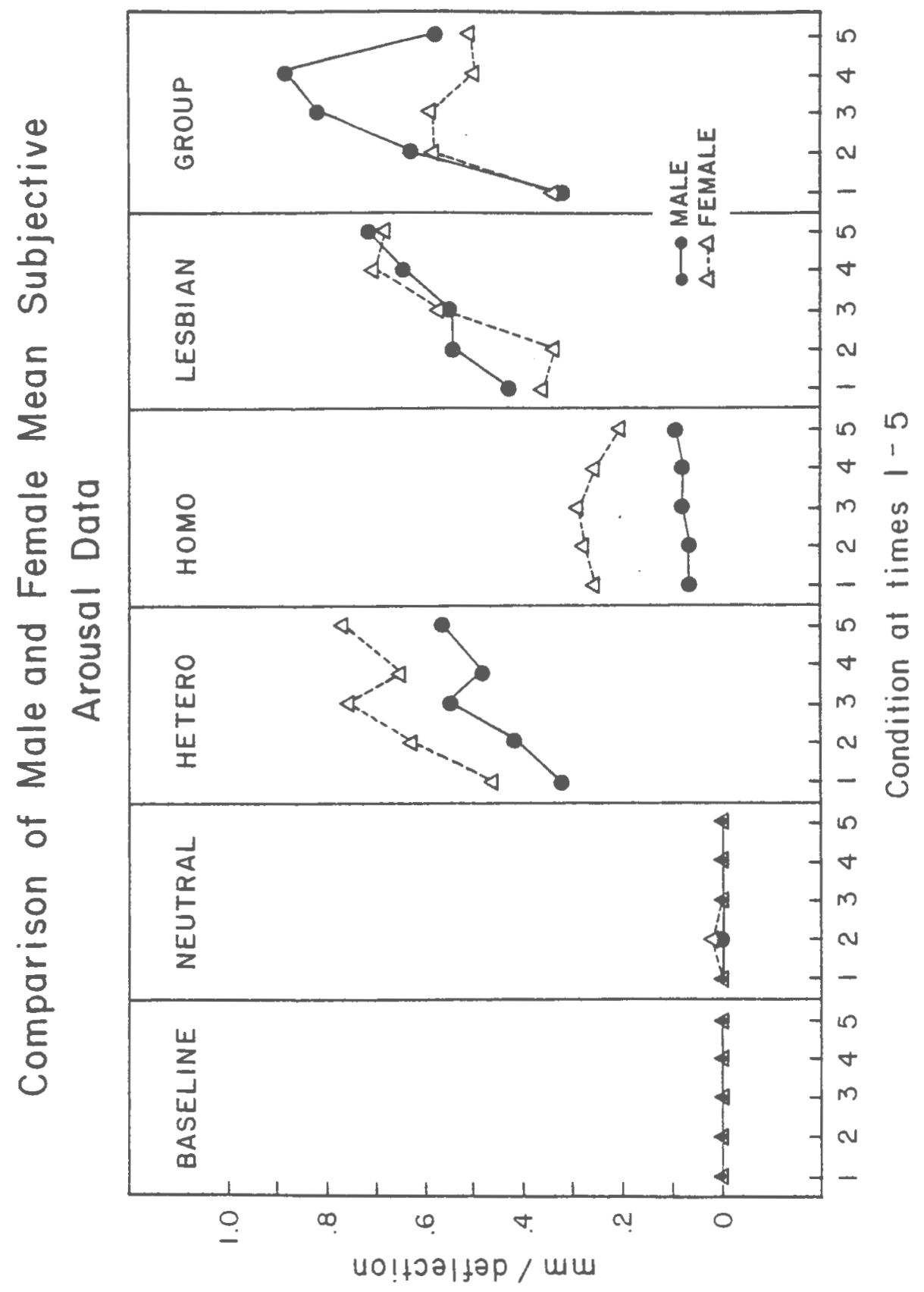




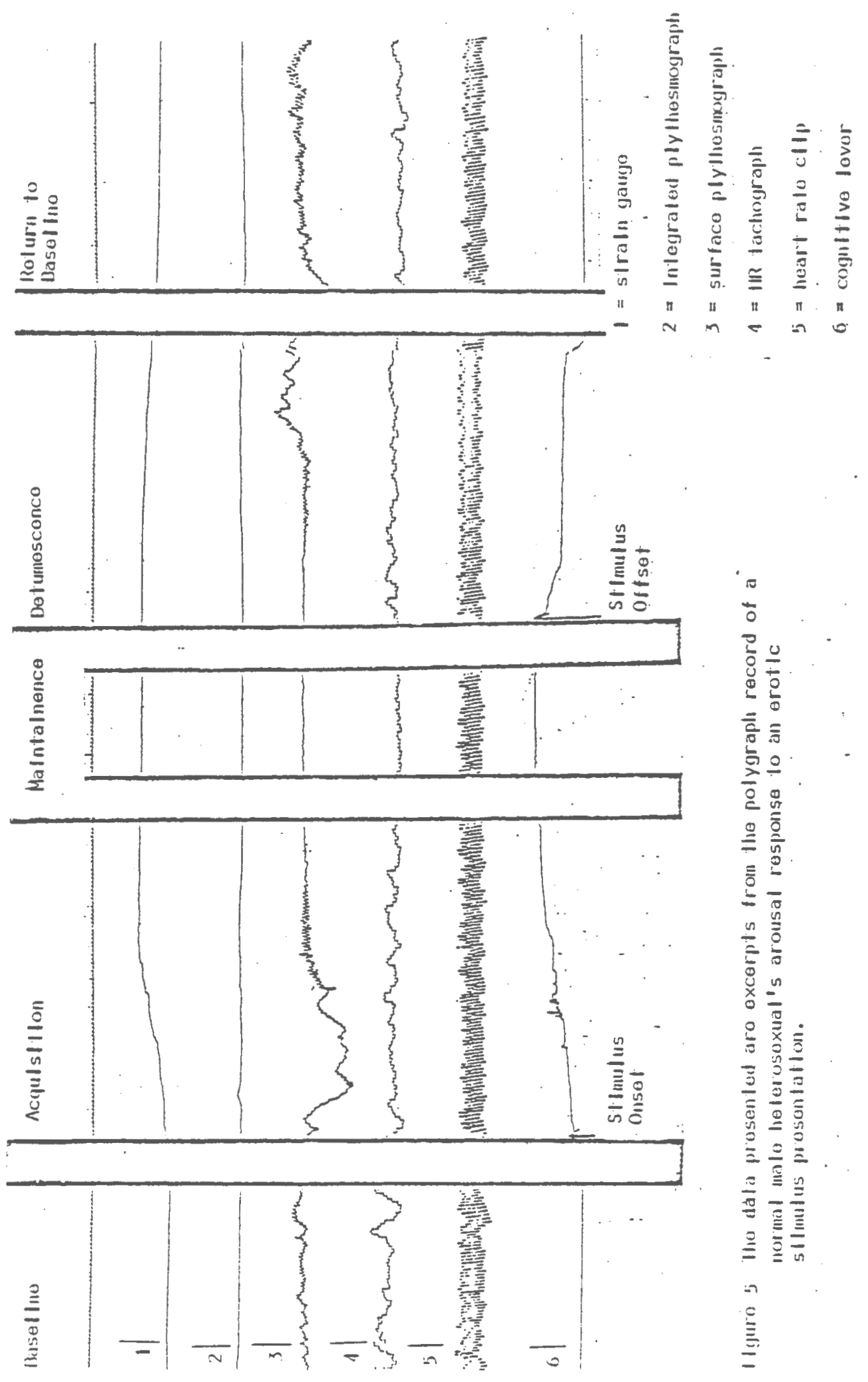


Appendix A

Instructions to Subjects:

You will be shows a variety of video tape scenes, some of which are related to each other, some of which are not. Please watch these scenes carefully. What you see may elicit thought of various scenes, sound, smells, tastes, feelings of touch or movement. Please try to get as involved as you can in the scenes. For example, you may imagine that you are actually there in the scene. Please try to respond, however, to only what you actualiy see in the film.

As you watch each scene and various aspects of each scene, move the lever. (experimentor points to lever) to indicate your level of sexual arousal. Let's practice with the lever. Moving the lever all the way forward to 10 indicates maximum or very intense sexual arousal. Moving it backward closest to you indicates 0 or no sexual arousal. Five indicates moderate arousal. 1 and 2 indicate very mild arousal. 3 and 4 indicate mild arousal. On the higher portion of the scale, 6 and 7 indicate moderately intense arousal, 8 and 9 indicate intense arousal. This is a linear scale. Therefore, 2 is twice as much as 1,10 twice as much as 5 .

$$
\begin{array}{ll}
10=\text { very intense } & 5=\text { moderate } \\
9=\text { intense } & 4=\text { mild } \\
8=\text { intense } & 3=\text { mild } \\
7=\text { moderately intense } & 2=\text { very mild } \\
6=\text { moderately intense } & 1=\text { very mild } \\
0=\text { not present }
\end{array}
$$


Let's practice for a moment. I vill say a number or phrase that indicates a particular level of arousal. Please move the lever as close to this number or degree of sexual arousal as you can. (The subject will then be given practice trials with feedback. He/She will continue practicing until there is no more than $5 \%$ error.)

Try to remember to use the lever continuously even when there are only small changes in how sexually aroused you think you are. Also use the lever continuously during breaks between the film. Keep your hand on the lever at all times.

You may base your devision on how sexually aroused you feel on as many or few cues, or signs, as you like. These cues may include your bodily response (feeling of warmth, tinglying, heart beat, etc.) or your thoughts or feelings about the scene.

One final note, there are no right or wrong ways to react to these scenes. Each person is unique. Also, your charts will be coded and kept confidential. 
Appendix B

Debriefing Questionnaire

1. As well as you can recall, which of the films did you find most sexually arousing?

2. On a scale from 0 to 100 , please rate the five films on how aroused you felt during each film. 0-would be no arousal and 100-would be maximum arousal.

Stimulus :

Films. Rating.

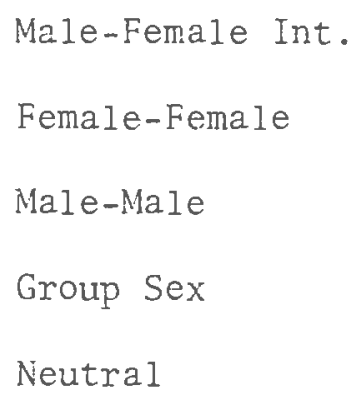

3. Were you surprised by your reaction to any of the films? If so, please explain.

4. Which of the films did you find least arousing?

5. Do you feel each film was long enough (two minutes) to allow you to become fully involved? If not, how long should each film be shown?

6. Did any of the films disturb you or "turn you off?" If so, which one(s). 
7. Did anything interfere with vour concentration while the films were being shown?

8. Do you feel our measurements real1y reflect your interest and arousal in each filn? If not, why not?

9. Did you have any difficulty using the lever? If so, in what way?

10. When using the lever, how did you judge your arousal? That is, did you attempt to have the lever reflect your physiological arousal or did you move the lever according to your feelings?

11. Do you feel there was a high correlation between the physiological measure and the lever. If not, why?

12. Was there any way we could have made the setting or situation more comfortable for you? 
Appendix C

Description of Erotic Film Sequences

Heterosexual Film - a black $\xi$ white film depicting a male and female engaged in intercourse.

Homosexual Film - a black \& white film depicting two males engaging in oral sex.

Lesbian Film - a black $\&$ white film depicting two women engaging in oral sex.

Group Sex Film - a color film depicting two males and two females engaging in heterosexual behaviors including intercourse and oral sex.

The characters in all of the films were nude throughout the film sequences. There was a musical soundtrack for each of the films. 